\title{
The Role of Transient Receptor Potential Cation Channels in $\mathrm{Ca}^{2+}$ Signaling
}

\author{
Maarten Gees, Barbara Colsoul, and Bernd Nilius \\ KU Leuven, Department of Molecular Cell Biology, Laboratory Ion Channel Research, \\ Campus Gasthuisberg, Herestraat 49, bus 802, Leuven, Belgium \\ Correspondence: Bernd.Nilius@med.kuleuven.be
}

The 28 mammalian members of the super-family of transient receptor potential (TRP) channels are cation channels, mostly permeable to both monovalent and divalent cations, and can be subdivided into six main subfamilies: the TRPC (canonical), TRPV (vanilloid), TRPM (melastatin), TRPP (polycystin), TRPML (mucolipin), and the TRPA (ankyrin) groups. TRP channels are widely expressed in a large number of different tissues and cell types, and their biological roles appear to be equally diverse. In general, considered as polymodal cell sensors, they play a much more diverse role than anticipated. Functionally, TRP channels, when activated, cause cell depolarization, which may trigger a plethora of voltage-dependent ion channels. Upon stimulation, $\mathrm{Ca}^{2+}$ permeable TRP channels generate changes in the intracellular $\mathrm{Ca}^{2+}$ concentration, $\left[\mathrm{Ca}^{2+}\right]_{\mathrm{i}}$, by $\mathrm{Ca}^{2+}$ entry via the plasma membrane. However, more and more evidence is arising that TRP channels are also located in intracellular organelles and serve as intracellular $\mathrm{Ca}^{2+}$ release channels. This review focuses on three major tasks of TRP channels: (1) the function of TRP channels as $\mathrm{Ca}^{2+}$ entry channels; (2) the electrogenic actions of TRPs; and (3) TRPs as $\mathrm{Ca}^{2+}$ release channels in intracellular organelles.

$\mathrm{T}$ ransient receptor potential (TRP) channels constitute a large and functionally versatile family of cation-conducting channel proteins, which have been mainly considered as polymodal unique cell sensors. The first TRP channel gene was discovered in Drosophila melanogaster (Montell and Rubin 1989) in the analysis of a mutant fly whose photoreceptors failed to retain a sustained response to maintained light stimuli. So far, more than 50 TRP channels have been identified with representative members in many species. The evolutionary first TRP channels in protists, chlorophyte algae,

choanoflagellates, yeast, and fungi are primary chemo-, thermo-, or mechanosensors (Cai 2008; Wheeler and Brownlee 2008; Chang et al. 2010; Matsuura et al. 2009). Many of these functions are remarkably conserved from protists, worms, and flies to humans (Montell 2005; Pedersen et al. 2005; Nilius et al. 2007; Damann et al. 2008). More than $50 \operatorname{trp}$ genes have been cloned so far that comprise approximately $20 \%$ of the known genes encoding ion channels. In mammals, 28 TRP channels were found and classified according to homology into 6 subfamilies: TRPC (canonical), TRPV (vanilloid),

Editors: Martin D. Bootman, Michael J. Berridge, James W. Putney, and H. Llewelyn Roderick Additional Perspectives on Calcium Signaling available at www.cshperspectives.org

Copyright (C) 2010 Cold Spring Harbor Laboratory Press; all rights reserved; doi: 10.1101/cshperspect.a003962

Cite this article as Cold Spring Harb Perspect Biol 2010;2:a003962 
TRPM (melastatin), TRPA (ankyrin), TRPML (mucolipin), and TRPP (polycystin) (Fig. 1). TRPs are expressed in numerous excitable and nonexcitable tissues, if not in all cell types. They are involved in manifold physiological functions, ranging from pure sensory functions, such as pheromone signaling, taste transduction, nociception, and temperature sensation, over homeostatic functions, such as $\mathrm{Ca}^{2+}$ and $\mathrm{Mg}^{2+}$ reabsorption and osmoregulation, to many other motile functions, such as muscle contraction and vaso-motor control. We are still at the very beginning of identifying all the diverse physiological functions of this intriguing ion channel family, and our knowledge about TRP channel expression and functioning in various tissues of mammals is limited. Accumulating evidence, however, suggests that TRP channels play prominent roles in the regulation of the intracellular calcium level in both excitable and nonexcitable cells.
The molecular architecture of TRP channels is reminiscent of voltage-gated channels and comprises six putative transmembrane segments (S1-S6), intracellular N- and C-termini, and a pore-forming reentrant loop between S5 and S6 (Gaudet 2008b). The length of the cytosolic tails varies greatly between TRP channel subfamilies, as do their structural and functional domains (for detailed reviews see Owsianik et al. 2006a). The TRPC and TRPM family members all contain a 25-amino-acid motif (the TRP domain) containing a TRP box C-terminal to S6, but this domain is not present in the other families. Although TRPC and TRPV family members contain 3-4 ankyrin repeats in their $\mathrm{N}$-terminal cytoplasmic tail, TRPA1 contains 14 ankyrin repeats, and they are not present in the other families. Lastly, TRPC and TRPM family members contain protein-rich sequences in the region $\mathrm{C}$-terminal of the TRP domain (known as the TRP box 2).

28 mammalian members (6 subfamilies)

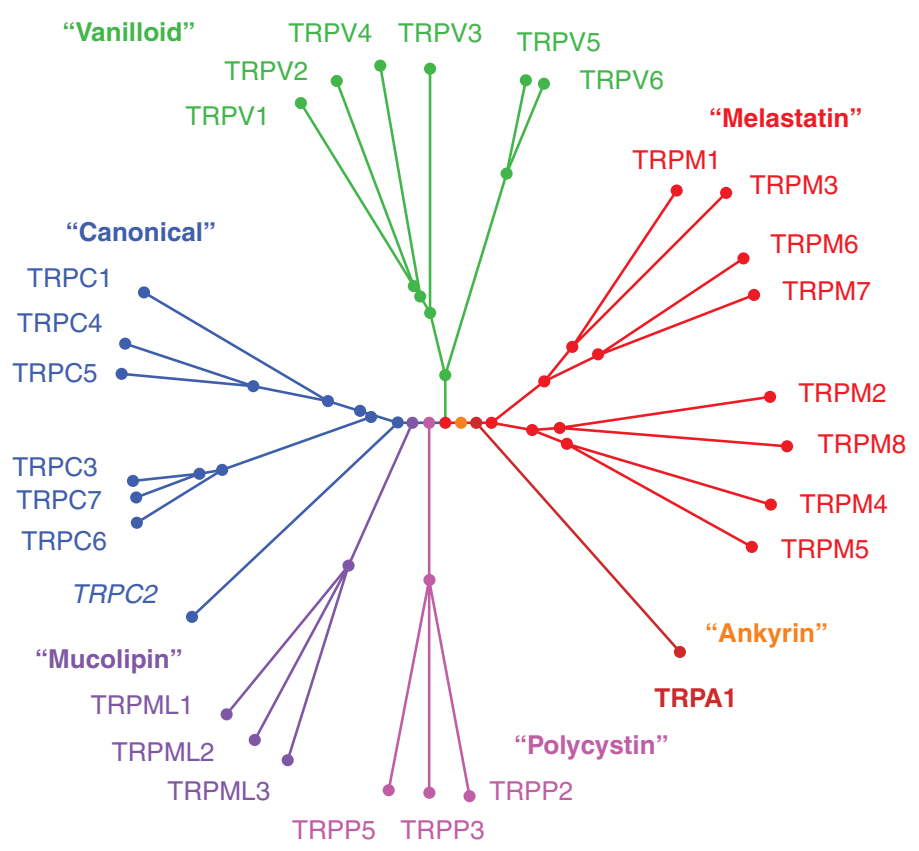

Figure 1. Phylogenetic tree of the mammalian TRP-channel superfamily. TRPC (canonical), TRPM (melastatin), TRPV (vanilloid), TRPA (ankyrin), TRPP (polycystin), and TRPML (mucolipin) are the only identified subfamilies in mammals. 
The TRP box is most likely important for binding of phosphatidylinositol phosphates, such as $\mathrm{PI}(4,5) \mathrm{P}_{2}$ (Rohacs 2007). So far, our knowledge of the three-dimensional structure is limited, as only parts of TRP proteins have been crystallized. Most of the TRP channels probably form tetramers, in which the capacity to function as homo- or heteromers is still a matter of debate. However, increasing evidence suggests heteromultimeric channel assembly within one subfamily, creating a variety of different channels with unique properties, as compared to homomers (Strubing et al. 2001; Smith et al. 2002). Topics to be explored further include the association with accessory proteins (e.g., beta subunits) and the forming of signalplexes (Montell 2003; Peng et al. 2007; Redondo et al. 2008), the various mechanisms of insertion and retrieval in and from the plasma membrane, and the general processes for the regulation of mainly intracellular location or their trafficking to the plasma membrane.

Importantly, most, if not all, TRP channels are modulated by $\mathrm{Ca}^{2+}$ itself, which generates positive or negative feedback loops. Thus, regarding the modulation of $\mathrm{Ca}^{2+}$ signaling, TRP channels provide a huge plasticity to the overall control of the intracellular $\mathrm{Ca}^{2+}$ concentration $\left[\mathrm{Ca}^{2+}\right]_{\mathrm{i}}$.

This review focuses on the functional role of TRP channels as modulators of intracellular $\mathrm{Ca}^{2+}$ signaling. Changes in the concentration of free cytosolic $\mathrm{Ca}^{2+}\left(\left[\mathrm{Ca}^{2+}\right]_{\mathrm{i}}\right)$ are of fundamental importance in different stages of the cell cycle, starting from the fertilization and embryonic pattern formation, to cell differentiation and proliferation, and cell death Furthermore, $\left[\mathrm{Ca}^{2+}\right]_{\mathrm{i}}$ plays a role in different cellular processes including transmitter release, muscle contraction, and gene transcription (Berridge et al. 2000). TRP channels can contribute to changes in $\left[\mathrm{Ca}^{2+}\right]_{\mathrm{i}}$, either by acting as $\mathrm{Ca}^{2+}$-entry pathways in the plasma membrane or by changing the membrane polarization; in this way modulating the driving force for $\mathrm{Ca}^{2+}$ entry mediated by alternative pathways. Alternatively, $\left[\mathrm{Ca}^{2+}\right]_{\mathrm{i}}$ can be elevated by the release from intracellular stores (Bootman et al. 2001). In addition, TRP channels are functionally linked with voltage-dependent $\mathrm{Ca}^{2+}$-entry channels that are activated by depolarization, for example, due to TRP gating. By changing the membrane potential and local $\mathrm{Ca}^{2+}$ gradients, TRP channels contribute to modulating the driving force for $\mathrm{Ca}^{2+}$ entry and provide intracellular pathways for $\mathrm{Ca}^{2+}$ release from cellular organelles.

For more detailed information on TRP channels regarding structure, gating, and special functional aspects, we refer a wealth of excellent reviews (Desai and Clapham 2005; Montell 2005; Ramsey et al. 2006; Nilius et al. 2007; Vennekens et al. 2008; Latorre et al. 2009; Vriens et al. 2009). For more detailed information, we direct the interested reader to databases such as http://www.ensembl.org/index.html and http://www.iuphar-db.org/DATABASE/ FamilyMenuForward?familyId=78 (see also Clapham et al. 2009).

\section{TRPs AS $\mathrm{Ca}^{2+}$ ENTRY CHANNELS}

\section{$\mathrm{Ca}^{2+}$ Permeable TRP Pores}

Although most TRPs are $\mathrm{Ca}^{2+}$ permeable, the selectivity varies greatly between the different members with $\mathrm{P}_{\mathrm{Ca}} / \mathrm{P}_{\mathrm{Na}}$ ratios ranging from $<1$ for TRPM1 to $>100$ for TRPV5 and TRPV6 (Fig. 2). This variance reflects different pore structures and obviously also differences in the dynamic pore behavior; for example, pore dilation by activations with various agonists (Chung et al. 2008; Karashima et al. 2010). In general, there is no high homology in the primary structure of the putative selectivity filter regions throughout all TRP subfamilies (Owsianik et al. 2006b). For TRPV5 and TRPV6, it is shown that the $\mathrm{Ca}^{2+}$-permeability depends on $\mathrm{D}^{542}$ in TRPV5 and the corresponding $\mathrm{D}^{541}$ in TRPV6 (Nilius et al. 2001). As TRPV5 and TRPV6 form homo- and heteromultimers, it appears that the $\mathrm{Ca}^{2+}$ selectivity in these channels depends on a ring of four aspartate residues in the pore of the channel, corresponding to the ring of four negativelycharged residues (aspartates and/or glutamates) in the pore of voltage-gated $\mathrm{Ca}^{2+}$ channels (Ellinor et al. 1995; Hoenderop et al. 2003). It is shown that neutralization of the $\mathrm{D}^{546}$ in 
M. Gees, B. Colsoul, and B. Nilius
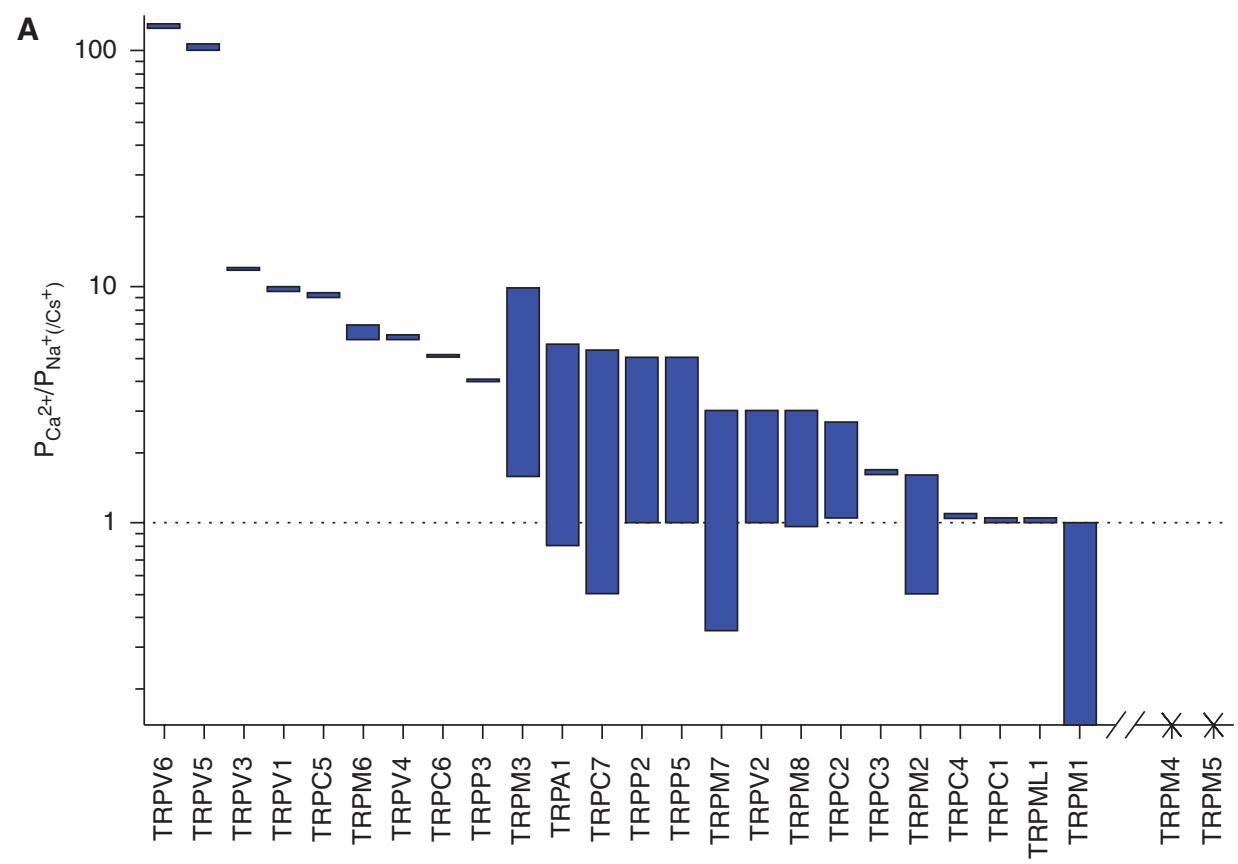

B

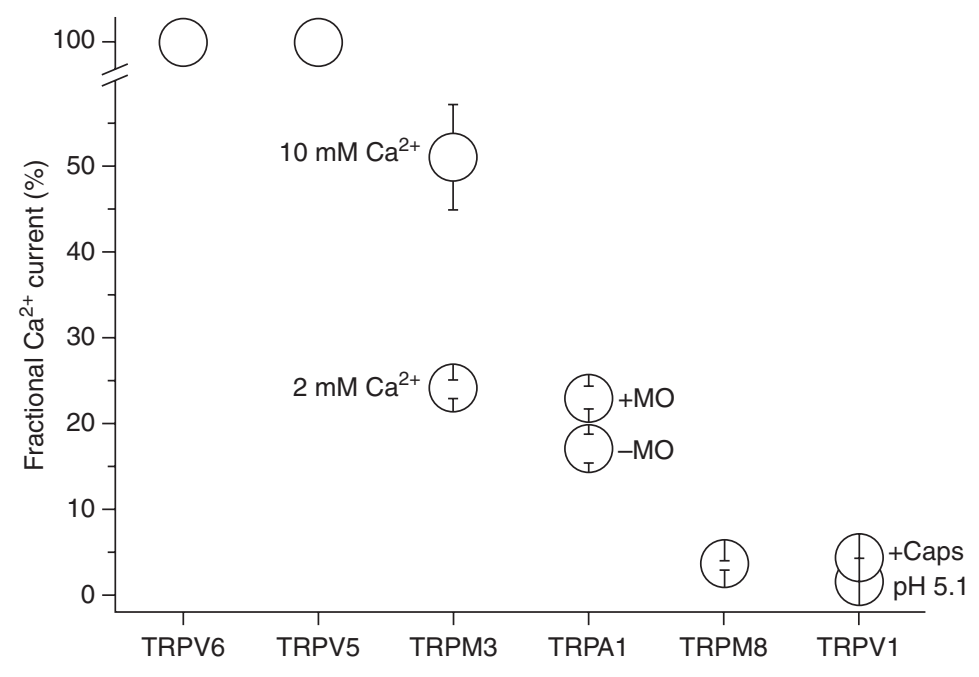

Figure 2. $\mathrm{Ca}^{2+}$ selectivity of TRP channels. (A) $\mathrm{Ca}^{2+}$ selectivity of TRP channels expressed as $P_{\mathrm{Ca}^{2+}} / P_{\mathrm{Na}^{+}\left(/ \mathrm{Cs}^{+}\right)}$ (depending on availability). Bars indicate maximal and minimal values found in literature; TRPM4 and TRPM5 are impermeable to $\mathrm{Ca}^{2+}$ (for TRPM1, values are deduced from Oancea et al. 2009). (B) Fractional $\mathrm{Ca}^{2+}$ current of TRP channels as found in literature (for TRPM3 Oberwinkler personal communication, see Drews et al. 2010).

TRPV1 and the corresponding $\mathrm{D}^{682}$ in TRPV4 also reduce the $\mathrm{Ca}^{2+}$ permeability. For TRPV4, additional neutralization of $\mathrm{D}^{672}$ reduces the divalent selectivity even further, while introducing a negative charge, instead of $\mathrm{M}^{680}$ abolishing the $\mathrm{Ca}^{2+}$ permeability completely
(Garcia-Martinez et al. 2000; Voets et al. 2002). More recently, it is shown that also in the Drosophila TRP an aspartate $\left(\mathrm{D}^{621}\right)$ plays an important role in determining the $\mathrm{Ca}^{2+}$ permeability (Liu et al. 2007a), whereas neutralization of the negative charges in the loops between TM5 and 
TM6 of TRPC5 $\left(\mathrm{E}^{543}, \mathrm{E}^{595}, \mathrm{E}^{598}\right)$ and TRPC1 (all seven, $\mathrm{D}$ to $\mathrm{N}$ and $\mathrm{E}$ to $\mathrm{Q}$ ) resulted in a decreased $\mathrm{La}^{2+}$ and $\mathrm{Ca}^{2+}$ permeability (Jung et al. 2003; Liu et al. 2003). This suggests that the negatively-charged residues determining the pore properties of TRPC1 and TRPC5 are located in the distal parts of the putative pore entrance. A pore study of TRPM4, which is impermeable to $\mathrm{Ca}^{2+}$, showed that substitution of residues $\mathrm{E}^{981}$ to $\mathrm{A}^{986}$ with the selectivity filter of TRPV6 yielded a functional channel with the gating hallmarks of TRPM4 (activation by $\mathrm{Ca}^{2+}$, voltage dependence) and with a TRPV6like sensitivity to block by extracellular $\mathrm{Ca}^{2+}$, $\mathrm{Mg}^{2+}$, and $\mathrm{Ca}^{2+}$ permeation (Nilius et al. 2005a). Two recent studies showed that $\mathrm{E}^{1024}$ and $\mathrm{D}^{1031}$ play an important role in the $\mathrm{Ca}^{2+}$ permeation through TRPM6, and that restoration of only two residues in the human TRPM2 (Q981E/P983Y) to the evolutionary, more ancient Nudix-linked channel residues, significantly increased the $\mathrm{Ca}^{2+}$ permeability, whereas introducing the newer sequence in TRPM7 (E1047Q/Y1049P) resulted in the loss of $\mathrm{Ca}^{2+}$ permeability (Topala et al. 2007; Mederos y Schnitzler et al. 2008). Another study showed that neutralizing the charges of residues $\mathrm{E}^{1052}$ and $\mathrm{E}^{1047}$ of TRPM7 and the corresponding residues in TRPM6 ( $\mathrm{E}^{1024}$ and $\mathrm{E}^{1029}$ ) reduced the $\mathrm{Ca}^{2+}$ permeation (Li et al. 2007).

Although pore structures have been considered as relatively stable, evidence is accumulating that for some TRP channels the pore diameter and also $\mathrm{Ca}^{2+}$ permeation depend on the mode of activation; for example, the activating agonist. Such dynamic pore behavior was first observed for P2X channels (Egan and Khakh 2004). Activation of TRPV1 leads to time-dependent and agonist-concentrationdependent increases in relative permeability to large cations and changes in $\mathrm{Ca}^{2+}$ permeability that parallels a pore dilation. TRPV1 agonists showed different capabilities for evoking ionic selectivity changes. Very likely, for TRPV1, protein kinase $\mathrm{C}$-dependent phosphorylation of $S^{800}$ in the TRPV1 C-terminus increases agonist-evoked ionic selectivity changes. Thus, the qualitative signaling properties of TRPV1 are dynamically modulated during channel activation, a process that probably shapes TRPV1 (Chung et al. 2008). A similar situation holds for TRPA1. From the relative permeability of the nonstimulated TRPA1 channel to cations of different sizes, a diameter of $\sim 11 \AA$ is calculated for the channel pore, which fits with the pore size of TRPM6, TRPV1, and TRPP2, but is significantly larger for the highly $\mathrm{Ca}^{2+}$ permeable channels TRPV5 and TRPV6 $(\sim 7.5 \AA$ and $5.4 \AA$ ). Under conditions of activation by electrophilic compounds such as AITC (allyl isothiocyanate, or mustard oil, MO), the TRPA1 channel undergoes a pore dilation by $\sim 3 \AA$. This dynamic pore behavior was coupled with an increased $\mathrm{Ca}^{2+}$ permeation and an increased fraction of $\mathrm{Ca}^{2+}$ contributing to the total current. Upon $\mathrm{MO}$ stimulation, $\mathrm{P}_{\mathrm{Ca}} / \mathrm{P}_{\mathrm{Na}}$ changed from $\sim 5.7$ to 7.9 , and the fractional $\mathrm{Ca}^{2+}$ current from $17.0 \%$ to $23.3 \%$. This pore dilation is probably not present for nonelectrophilic agonists and also disappeared when a negatively-charged residue in the pore, $\mathrm{D}^{918}$, was changed to noncharged residues. Again, this negative charge in the TRPA1 pore determines the $\mathrm{Ca}^{2+}$ entry (Chen et al. 2009; Karashima et al. 2010). Also, for TRPV5, a pH-dependent pore dilation has been described (Yeh et al. 2005). This dynamic pore behavior adds a new regulation mechanism to agonist-induced $\mathrm{Ca}^{2+}$ entry. Pore dilation, modulation of the fractional $\mathrm{Ca}^{2+}$ current, and changes of the $\mathrm{Ca}^{2+}$ permeation are modulator properties for $\mathrm{Ca}^{2+}$ signaling in likely many TRP channels.

Thus, depending on the pore structure, TRP channels vary in their pore size and in the permeation for $\mathrm{Ca}^{2+}$, which is indicated by the $\mathrm{P}_{\mathrm{Ca}} / \mathrm{P}_{\mathrm{Na}}$ (or $\mathrm{P}_{\mathrm{Cs}}$ ) ratios. Obviously, the $\mathrm{Ca}^{2+}$ permeation also varies under different experimental conditions, might be influenced by associated proteins, and even shows a dynamic behavior for some TRP channels. Figure 2 gives an overview of $\mathrm{Ca}^{2+}$ permeation properties and their variability.

\section{TRPCs}

The mammalian members of the TRPC family can by divided into 4 subfamilies on the basis of functional similarities and sequence 
alignment: TRPC1, TRPC2, TRPC3/6/7, and TRPC4/5. TRPC channels in general are nonselective $\mathrm{Ca}^{2+}$ permeable cation channels, but the selectivity ratio $\mathrm{P}_{\mathrm{Ca}} / \mathrm{P}_{\mathrm{Na}}$ varies significantly between the different family members (see Fig. 2). With a few exceptions, expression of TRPC family members is broad; thus, generally, most cell types contain multiple TRPCs (for examples, see Montell et al. 2002; Montell 2005). The characterization is further complicated by different heterotetramers. It is shown that TRPC1 can form heteromers with TRPC4 and 5 , and the TRPC subfamilies TRPC4/5, and TRPC $3 / 6 / 7$ can form heteromers among themselves, with properties that can differ significantly from those of the homotetramers (Strubing et al. 2001; Goel et al. 2002; Hofmann et al. 2002; Strubing et al. 2003; Schilling and Goel 2004). Activation of TRPC channels occurs mainly via different isoforms of phospholipase C (PLC) (Venkatachalam et al. 2002).

The relation between the constituents, STIM1 and ORAI1, of the best characterized store-operated $\mathrm{Ca}^{2+}$ channel (SOC) carrying $\mathrm{I}_{\text {CRAC }}$ and the contribution of TRPC channels is still a matter of dispute. It was first shown that TRPC1/STIM1 and ORAI1 very likely form ternary complexes to contribute to a SOC channel (Ambudkar et al. 2007). ORAI1 proteins may interact with TRPCs and act as regulatory subunits that confer STIM1-mediated store depletion sensitivity to these channels (Lu et al. 2010; Liao et al. 2007). STIM1 has been shown to bind to TRPC1, TRPC4, and TRPC5 and is therefore involved in storeoperated $\mathrm{Ca}^{2+}$ entry (SOCE) (Yuan et al. 2007; Sours-Brothers et al. 2009). The involvement of TRPC channels in SOCE may depend on special membrane structures, such as lipid rafts (Pani et al. 2008). In general, a majority of reports described TRPC1 as a store-operated channel whose gating mechanism is still to be elucidated (Worley et al. 2007; Kim et al. 2009c; $\mathrm{Ng}$ et al. 2009). So far, as concluded from a plethora of experimental evidence, TRPC channels might, under certain circumstances, act as SOCs, but are to be clearly distinguished from the calcium-release-activated calcium channels, as they show distinct properties: high $\mathrm{Ca}^{2+}$ selectivity; very small single channel conductance; distinct $\mathrm{Ca}^{2+}$ dependent modulation, e.g., fast and slow inactivation; and slow decay in divalent free solutions (for reviews and more detailed descriptions, see Vaca 2010; Bolotina 2008; Birnbaumer 2009; Kiselyov and Patterson 2009; Yuan et al. 2009).

TRPC1 (ENSG00000144935; TRPC1) is activated by the neuronal metabotropic glutamate receptor mGluR1 and thus contributes to the slow excitatory postsynaptic potential (EPSP) (Kim et al. 2003). Furthermore, TRPC1 provides an important route for $\mathrm{Ca}^{2+}$ entry after agonist, growth factor, and PKC induction in different cell types such as endothelial cells (Kamouchi et al. 1999; Nilius and Droogmans 2001; Tiruppathi et al. 2006), platelets (Authi 2007), smooth muscle cells (Dietrich et al. 2006), and B-lymphocytes (Mori et al. 2002). One report identifies TRPC1 as the mechanosensitive cation channel, responsible for transducing membrane stretch in cationic currents (Maroto et al. 2005), but this is disputed (Gottlieb et al. 2008). In Trpc1 KO mice, it is shown that the salivary gland fluid secretion regulated by neurotransmitters is severely reduced (Liu et al. 2007b). TRPC1 is also activated by orexin $\mathrm{A}$, a peptide hormone associated to the regulation of sleep/wakefulness states, alertness, and appetite (Larsson et al. 2005). More recently, it is shown that knockdown of Trpcl in zebrafish impaired angiogenesis, an effect that could be rescued by reintroducing TRPC1, which is reminiscent of the role of TRPCs in axon guidance (Yu et al. 2010).

Trpc2 (ENSMUSG00000058020; TRPC2) in humans is a pseudogene (Yildirim and Birnbaumer 2007), but in rodents it plays an important role in pheromone detection via the vomeronasal sensory neurons (VSN) (Yildirim and Birnbaumer 2007). TRPC2 is also shown to be important for the $\mathrm{Ca}^{2+}$ signaling in spermatozoa after egg ZP3 stimulation (Yildirim and Birnbaumer 2007). Lastly, TRPC2 is shown to be involved in $\mathrm{Ca}^{2+}$ release from the intracellular stores (Gailly and Colson-Van Schoor 2001; Tong et al. 2004; Yildirim and Birnbaumer 2007). 
Expression of TRPC3 (ENSG00000138741; TRPC3) is highest in brain, smooth, and cardiac muscle cells (Riccio et al. 2002b; Clapham 2003). TRPC3 is a constitutively active receptoroperated channel that can be further stimulated by DAG (Lemonnier et al. 2008). As all TRPCs, TRPC3 can interact directly via a CIRB region with both $\mathrm{IP}_{3} \mathrm{R}$ and Calmodulin (CaM). TRPC3 channel activation by $\mathrm{IP}_{3}$ can lead to the constriction of cerebral arteries (Wedel et al. 2003; Xi et al. 2008) and is involved in synaptogenesis and growth-cone guidance (Amaral and Pozzo-Miller 2007b). The Trpc3 gene was found to be damaged in human T-cell mutants defective in $\mathrm{Ca}^{2+}$ influx; introduction of the complete human TRPC3 cDNA into those mutants rescued the $\mathrm{Ca}^{2+}$ currents, as well as TCRdependent $\mathrm{Ca}^{2+}$ signals (Philipp et al. 2003). TRPC3 activation by purinergic receptors results in both $\mathrm{Ca}^{2+}$ influx and depolarization of endothelial cells and vasoconstriction in smooth muscle cells (Ahmmed and Malik 2005; Kwan et al. 2007).

Expression of TRPC4 (ENSG00000100991; TRPC4) is found in endothelium and smooth muscle cells (Beech 2005; Tiruppathi et al. 2006), intestinal pacemaker cells (ICC) (Kim et al. 2006), in many brain regions (Zechel et al. 2007), adrenal glands (Philipp et al. 2000), and in kidneys (Freichel et al. 2005). It is suggested that TRPC4 is an essential component of the nonselective cation channel involved in neuromodulation of stomach smooth muscle after muscarinic stimulation (Lee et al. 2005). Furthermore, a reduced agonist-induced $\mathrm{Ca}^{2+}$ entry and vasorelaxation is shown in the vascular endothelium of TRPC4-deficient mice (Freichel et al. 2001).

Similar to TRPC4, TRPC5 (ENSG00000072315; TRPC5) is expressed in multiple tissues, including brain tissue (Hofmann et al. 2000). In the CNS, it is shown that TRPC5 can form heteromeric cation channels with TRPC1, and these heteromultimers may play an important role during brain development (Strubing et al. 2001; Strubing et al. 2003). In neurons, TRPC5 is loaded to vesicular packages for neuronal transport via association with synaptotagmin and stathmin-2 (Greka et al. 2003).
TRPC5 shows a striking voltage dependence, shifting between outwardly rectifying and doubly rectifying shapes (called phases) depending on the time in the activation-deactivation cycle. These phase transitions can be modulated by external factors such as $\mathrm{La}^{3+}$ and the scaffolding protein EBP50 (Obukhov and Nowycky 2004; Obukhov and Nowycky 2008). Vesicular insertion of TRPC5 from a subplasmalemmal reserve pool is shown to be regulated by EGF-RTK, in a manner depending on PI3K, Rac, and phosphatidylinositol 4-phosphate 5-kinase (PIP(5)K) (Bezzerides et al. 2004). This process is shown to be important for the regulation of hippocampal neurite length and growth-cone morphology (Bezzerides et al. 2004). Noticeably, TRPC5 is required for muscarinic persistent responses involved in establishing a transient working memory in the entorhinal cortex (Zhang et al. 2010). More recently, it was shown that TRPC5 is important for amygdala function and fear-related behavior (Riccio et al. 2009). TRPC5 is also activated by nitric oxide (NO), which was shown to be achieved by nitrosylation of residues $C^{553}$ and $C^{558}$ (Yoshida et al. 2006).

TRPC6 (ENSG00000137672; TRPC6) and TRPC7 (ENSG00000069018; TRPC7) are closely related, but whereas expression of TRPC6 is highest in the lung and brain, TRPC7 is mainly expressed in the kidney and pituitary gland (Hofmann et al. 2000; Riccio et al. 2002a; Montell 2005). It is shown that thrombin activation of TRPC6 can induce $\mathrm{Ca}^{2+}$ entry in platelets (Hassock et al. 2002). The channel is also shown to be an important part of the vascular $\alpha_{1}$-activated $\mathrm{Ca}^{2+}$-permeable cation channel in smooth muscle (Inoue et al. 2001; Jung et al. 2002). Furthermore, Trpc6 KO mice showed an elevated blood pressure and increased vascular smooth muscle contractility that was only partly recovered by the constitutively-active TRPC3-type channels, which are up-regulated in the smooth muscle cells of Trpc6 KO mice (Dietrich et al. 2005). Lastly, TRPC6 channel activity at the slit diaphragm is shown to be essential for proper regulation of podocyte structure and function (Reiser et al. 2005; Graham et al. 2007). The functional 
role of TRPC7 is still unclear, but it is suggested that TRPC7 conducts $\mathrm{Ca}^{2+}$ in AT1-induced myocardial apoptosis via a calcineurin-dependent pathway and can thereby contribute to the process of heart failure (Satoh et al. 2007).

\section{TRPVs}

Similar to the TRPC family, the TRPV (vanilloid) family can be divided into four subfamilies on the basis of structure and function, namely TRPV1/TRPV2, TRPV3, TRPV4, and TRPV5/6 (Vennekens et al. 2008). As mentioned above, TRPV5 and 6 are the only highly $\mathrm{Ca}^{2+}$-selective channels in the TRP channel family (Nilius et al. 2000; Vennekens et al. 2000; Nilius et al. 2001), whereas TRPV1-4 are nonselective cation channels (permeability ratio $\mathrm{P}_{\mathrm{Ca}} / \mathrm{P}_{\mathrm{Na}}$ between $\sim 1$ and $\sim 15$; see Fig. 2 ) that are activated by temperature and by numerous other stimuli (Nilius et al. 2003; Nilius et al. 2004; Vennekens et al. 2008; Vriens et al. 2009). All channels of the TRPV family contain 3-6 $\mathrm{NH}_{2}$-terminal ankyrin repeats (for details, see Gaudet 2008a; Gaudet 2008b; Gaudet 2009).

TRPV1 (ENSG00000196689; TRPV1) was the first mammalian TRPV family member to be discovered and has been studied most extensively. Expression of TRPV1 was first identified in the pain-sensitive neurons of the dorsal root ganglion (DRG) and trigeminal ganglion (TG) neurons, but is also present in the terminals of spinal and peripheral nerves. TRPV1 expression is also shown in multiple non-neuronal cell types (Hayes et al. 2000). Activation of TRPV1 is voltage-dependent and can be induced by capsaicin and temperature $\left(>42^{\circ} \mathrm{C}\right.$ ) (Voets et al. 2004a). Trpv1 KO mice showed the importance of the channel in the detection and integration of different painful chemical and thermal stimuli (Caterina et al. 1997). In the pancreas, it is shown that TRPV1 is involved in the release of substance $\mathrm{P}$ (Nathan et al. 2001). In the bladder, TRPV1 is an important target for the treatment of cystitis-induced bladder overactivity, but the exact localization is still under debate (De Ridder and Baert 2000; Charrua et al. 2007; Wang et al. 2008; Everaerts et al. 2009).
TRPV2 (ENSG00000187688; TRPV2) has $50 \%$ sequence identity to TRPV1 and is also expressed in DRG neurons, different brain regions, and non-neuronal tissues, including GI tract and smooth muscle cells (Vennekens et al. 2008). Similar to TRPV1, TRPV2 is also activated by heat but only at higher, noxious temperatures $\left(>52^{\circ} \mathrm{C}\right)$ compared to TRPV1 (Caterina et al. 1999). Growth factors, such as insulin-like growth factor (IGF-1), can activate TRPV2 by vesicular insertion in the membrane, a process that can be associated to myocyte degeneration caused by the disruption of dystrophin-glycoprotein complexes (Kanzaki et al. 1999; Iwata et al. 2003). Furthermore, in a dystrophin-deficient $(m d x)$ mouse, a model for muscular dystrophy, it was shown that expression of a dominant-negative TRPV2 reduced the muscle damage (Iwata et al. 2009). TRPV2 has also been described as a mechano-sensor in vascular smooth muscle cells, as it can function as a stretch-activated channel (Muraki et al. 2003; Beech et al. 2004). More recently, it is shown that TRPV2 is of fundamental importance in innate immunity, as early phagocytosis was impaired in macrophages lacking the cation channel (Link et al. 2010).

TRPV3 (ENSG00000167723; TRPV3) is expressed in DRG and TG neurons, the brain, the tongue, and the testis (Smith et al. 2002; Xu et al. 2002; Chung et al. 2003; Chung et al. 2005). Expression is also high in the skin, keratinocytes, and in the cells surrounding hair follicles (Peier et al. 2002b; Gopinath et al. 2005; Moqrich et al. 2005; Asakawa et al. 2006; $\mathrm{Xu}$ et al. 2006; Mandadi et al. 2009). TRPV3 is activated by innocuous warm temperatures $\left(>30-33^{\circ} \mathrm{C}\right)$, and the natural compounds camphor, thymol carvacrol, and eugenol, which are also potent sensitizers for temperature activation of the channel (Peier et al. 2002b; Xu et al. 2002; Moqrich et al. 2005; Xu et al. 2006). The importance of TRPV 3 as a temperature sensor is shown in Trpv3 $\mathrm{KO}$ mice, in which the responses to innocuous and noxious heat are dramatically diminished, whereas responses to other sensory modalities remained unaltered (Moqrich et al. 2005). More recently, it is shown that heating of keratinocytes causes 
release of ATP that can consequently activate termini of neighboring DRG neurons, a process that is compromised in keratinocytes from TRPV3-deficient mice (Mandadi et al. 2009). TRPV3 is required for forming the skin-barrier function and keratinocytes cornification and forms a signalplex with TGF- $\alpha /$ EGFR (Cheng et al. 2010a).

TRPV4 (ENSG00000111199; TRPV4) is a channel that is widely expressed in the brain, DRG neurons, and multiple non-neuronal tissues including bone, chondrocytes, insulinsecreting $\beta$-cells, keratinocytes, smooth muscle cells, hair cells of the inner ear, and different epithelial cell types (Vennekens et al. 2008; Everaerts et al. 2010). TRPV4 can be activated by moderate temperatures $\left(>24^{\circ} \mathrm{C}\right)$ and is, as such, constitutively active at normal body temperatures. Other activating stimuli include shear stress, cell swelling, anandamide, arachidonic acid, and $4 \alpha$-phorbol 12,13-didecanaote (4 $\alpha$-PDD) (Watanabe et al. 2002a; Watanabe et al. 2002b; Nilius et al. 2003; Watanabe et al. 2003; Nilius et al. 2004). It is reported that TRPV4 plays a role in thermoregulation via epidermal keratinocytes (Chung et al. 2003; Chung et al. 2004). As a mechanical and osmotic stimulus-induced nociceptor, TRPV4 seems important in DRGs and TGs (Alessandri-Haber et al. 2003; Liedtke and Friedman 2003; Suzuki et al. 2003). Lastly, it is shown that TRPV4 expressed in osteoblasts and osteoclasts may play a role in bone formation and remodelling (Masuyama et al. 2008; Mizoguchi et al. 2008) whereas in chondrocytes, it is shown to regulate the Sox9 pathway involved in the regulation of chondrocyte polarity and differentiation and in endochondral ossification (Muramatsu et al. 2007).

TRPV5 (ENSG00000127412; TRPV5) and TRPV6 (ENSG00000165125; TRPV6) are close homologs and the only members of the TRP family that are highly $\mathrm{Ca}^{2+}$-selective. TRPV5 and TRPV6 can function as homomers, but TRPV5/6 heterotetramers are also formed (Hoenderop et al. 2003). Both channels are constitutively active and are essential for $\mathrm{Ca}^{2+}$ reabsorption in the kidney (TRPV5) and in the intestine (TRPV6) (den Dekker et al. 2003;
Nijenhuis et al. 2003a; Nijenhuis et al. 2003b). Both channels are tightly regulated by extracellular and intracellular $\mathrm{Ca}^{2+}$ concentrations, although their kinetics differ (Voets et al. 2001; Nilius et al. 2002; Voets et al. 2003; Hoenderop et al. 2005). The striking $\mathrm{Ca}^{2+}$-dependent inactivation probably reflects a $\mathrm{Ca}^{2+}$-induced $\mathrm{PI}(4,5) \mathrm{P}_{2}$ depletion (Thyagarajan et al. 2008; Thyagarajan et al. 2009).

\section{TRPMs}

The members of the TRPM (melastatin) family are divided into 4 groups on the basis of sequence homology: TRPM $1 / 3$, TRPM $2 / 8$, TRPM4/5, and TRPM 6/7. $\mathrm{Ca}^{2+}$ permeability in the TRPM family ranges from impermeable to $\mathrm{Ca}^{2+}$ (TRPM4 and 5) to highly $\mathrm{Ca}^{2+}$ permeable (TRPM3, 6 and 7; see Fig. 2). Unlike the previously-discussed TRP channels, TRPM channels lack the N-terminal ankyrin repeats.

Lower expression levels of TRPM1 (ENSG00000134160; TRPM1) in malignant melanoma cell lines suggested that TRPM1 had a tumor suppressor function, but this was debated in further research (Duncan et al. 1998; Duncan et al. 2001; Miller et al. 2004). It is thought that TRPM1 is a constitutively open, nonselective cation channel, but little is known about the functional properties and cellular functions of this channel, partly because of the huge number of different splice variants. More recently, it was shown that a TRPM1 long-form (TRPM1-L) plays an important role in the ON pathway of retinal bipolar cells, and this might explain the complete congenital stationary night blindness seen in patients with mutations in Trpm1 (Koike et al. 2010; Audo et al. 2009; Li et al. 2009; Shen et al. 2009; van Genderen et al. 2009).

TRPM2 (ENSG00000142185; TRPM2) is a chanzyme, forming a nonselective cation channel fused C-terminally to an enzymatic ADPribose pyrophosphatase domain (Perraud et al. 2001; Perraud et al. 2003). Expression of TRPM2 is found highest in the brain, but is also found in different peripheral cell types (Kraft and Harteneck 2005). 
It is shown that activation of TRPM2 causes predisposition to apoptosis and cell death and that inhibition of TRPM2 is neuroprotective, probably because TRPM2 is activated by $\mathrm{H}_{2} \mathrm{O}_{2}$ and functions as a sensor for the cellular redox status (Kuhn et al. 2005; McNulty and Fonfria 2005; Zhang et al. 2006). This activation is prevented by a truncated TRPM2 isoform (TRPM2-S), generated by alternative splicing of the full-length protein (TRPM2-L) (Zhang et al. 2003a).

Transcription of TRPM3 (ENSG00000083067; TRPM3), similar to TRPM1, results in a number of different mRNA species, and this variability is further enhanced by the presence of different starting positions and C-terminal ends (Grimm et al. 2003; Lee et al. 2003). Expression of TRPM3 has been shown in the human brain and kidney, although it was undetectable in a mouse kidney (Grimm et al. 2003; Lee et al. 2003). TRPM3 forms a channel permeable to divalent cations and is activated by D-erythro-sphingosine, pregnenolone sulfate, activation of an endogenous muscarinic receptor, and by a decreased extracellular osmolarity. This activation by hypotonicity argues for a role for TRPM3 in the renal osmo-homeostasis (Grimm et al. 2003; Lee et al. 2003; Grimm et al. 2005).

TRPM4 (ENSG00000130529; TRPM4) and TRPM5 (ENSG00000070985; TRPM5) are two closely-related cation channels that are ubiquitously expressed; whereas TRPM4 expression is highest in the heart, pancreas, and placenta, TRPM5 expression is found mainly in the intestine, taste buds, and pancreas but also in the stomach, lung, testis, and brain (Ullrich et al. 2005; Fonfria et al. 2006; Zhang et al. 2003b; Kokrashvili et al. 2009; Colsoul et al. 2010). As these channels are impermeable to $\mathrm{Ca}^{2+}$, they do not function as $\mathrm{Ca}^{2+}$-entry channels. They do, however, play a role in $\left[\mathrm{Ca}^{2+}\right]_{\mathrm{i}}$ modulation, which is discussed later.

TRPM6 (ENSG00000119121; TRPM6) and TRPM7 (ENSG00000092439; TRPM7) are highly homologous channel kinases, with expression in the kidney and intestine for TRPM6 and ubiquitously for TRPM7 (Runnels et al. 2001; Monteilh-Zoller et al. 2003; Voets et al. 2004b). TRPM6 is highly permeable to $\mathrm{Mg}^{2+}$, activated by low $\left[\mathrm{Mg}^{2+}\right]_{\mathrm{I}}$, and is shown to be important in the $\mathrm{Mg}^{2+}$ homeostasis and reabsorption in the kidney and intestine (Schlingmann et al. 2002; Voets et al. 2004b; Schlingmann et al. 2005). Apart from $\mathrm{Mg}^{2+}$ and $\mathrm{Ca}^{2+}$, TRPM7 is also permeable to divalent cations and is responsible for the uptake of these trace metal ions (Monteilh-Zoller et al. 2003). Furthermore, TRPM7 is shown to be involved in the regulation of the cell cycle and in neurotoxic death (Wolf and Cittadini 1999; Aarts et al. 2003; Aarts and Tymianski 2005). Zebrafish with a TRPM7 mutation have a defective skeletogenesis with kidney-stone formation and have an increased cell death of the melanophores (Elizondo et al. 2005; McNeill et al. 2007).

TRPM8 (ENSG000000144481; TRPM8) cDNA was isolated from prostate cancer cells, but was later shown to be widely expressed, with high expression in a subset of pain- and temperature-sensitive neurons (Tsavaler et al. 2001; McKemy et al. 2002; Peier et al. 2002a). TRPM8 is activated by cold temperatures $\left(8-28^{\circ} \mathrm{C}\right)$ and by chemicals such as icilin and menthol, known to produce a cooling sensation (Voets et al. 2004a; Dhaka et al. 2006). Although the role for TRPM8 in the progression of cancer cells is highly debated, it is clear that it acts as a cold thermosensor in sensory neurons.

\section{TRPA}

TRPA1 (ENSG00000104321; TRPA1) is the only member of the TRPA (ankyrin) family characterized by the $14 \mathrm{NH}_{2}$ terminal ankyrin repeats (Story et al. 2003). It is expressed in hair cells and in the sensory DRG and TG neurons (Story et al. 2003; Corey et al. 2004). TRPA1 is activated by noxious cold and different chemicals including allyl isothiocyanate (the pungent compound in mustard oil), allicin (from garlic), cinnamaldehyde (from cinnamon), mentol (from mint), tetra-hydrocannabinoid (from marijuana), nicotine (from tobacco) and bradykinin (Patapoutian et al. 2003; Story et al. 2003; Macpherson et al. 2005; Karashima et al. 2007; Macpherson et al. 2007; Karashima 
TRP Channels Modulate $\mathrm{Ca}^{2+}$ Signaling

et al. 2009; Talavera et al. 2009). TRPA1 plays an important role in cold temperature and chemical-induced nociception and in the transduction mechanism through which these irritants and other endogenous proalgesics elicit inflammatory pain (Story et al. 2003; Bautista et al. 2006; Kwan et al. 2006; Karashima et al. 2009). TRPA1 is also suggested as an interesting target for the treatment of cough in humans, as TRPA1 agonists can evoke coughing, an effect that is reduced in the presence of TRPA 1 antagonists (Andre et al. 2009; Birrell et al. 2009).

\section{TRPPs}

The TRPP (polycystin) family comprises eight members, from which only the polycystic kidney disease 2 (PKD2 or TRPP2) and the PKD2-like (TRPP3 and TRPP5, or, according to Clapham et al. 2009, named TRPP1, TRPP2, and TRPP3) are shown to be channels. The cation-permeable TRPP channels have a $\mathrm{P}_{\mathrm{Ca}} /$ $\mathrm{P}_{\mathrm{Na}}$ between 1 and 5 and do not contain a TRP domain nor ankyrin repeats (see Fig. 2) (Delmas 2004; Delmas et al. 2004).

TRPP2 (ENSG00000118762; TRPP2) is widely expressed but most present in the kidney. It is localized to both motile and nonmotile cilia, in which it seems to be a mechanosensor involved in the nodal ciliary movement (Delmas et al. 2004). TRPP2's role in this crucial process for correct organ localization during development is consistent with the left to right asymmetry defects found in animal models lacking TRPP2 (Pennekamp et al. 2002; Bisgrove et al. 2005). Via a coiled-coil domain, TRPP2 and TRPP1 can form a functional polycystin complex, which appears to be essential for pressure-sensing in the kidney, a process altered in autosomal-dominant polycystic kidney disease (Sharif-Naeini et al. 2009).

TRPP3 (ENSG00000107593; TRPP3) and TRPP5 (ENSG00000078795; TRPP5) are less studied, and although TRPP3 is widely expressed, expression of TRPP5 is mainly shown in the testes (Keller et al. 1994; Nomura et al. 1998; Guo et al. 2000). The $\mathrm{Ca}^{2+}$-permeable, nonselective TRPP3 channel is shown to be activated by alkalization and, as such, is thought to be involved in acid-sensing of sour tastes and in the cerebrospinal fluid (Huang et al. 2006; Ishimaru et al. 2006; Shimizu et al. 2009). TRPP5 might play a role in calcium homeostasis and, as such, may contribute to cell proliferation, apoptosis, (Xiao et al. 2009) and to spermatogenesis (Guo et al. 2000; Chen et al. 2008; Xiao et al. 2009).

\section{TRPMLS}

The TRPML (mucolipin) family contains three mammalian members: TRPML1 (ENSG00000090674; TRPML1), TRPML2 (ENSG00000153898; TRPML2), and TRPML3 (ENSG00000055732; TRPML3). The TRPML proteins show only low homology with the other TRP channels and are comparatively shorter. As TRPML ion channels are mainly localized in endosomes and lysosomes, their characteristics will be further elucidated below (Cheng et al. 2010b).

\section{TRP CHANNELS DEPOLARIZE EXCITABLE CELLS AND CHANGE INWARDLY-DRIVING FORCES FOR $\mathrm{Ca}^{2+}$ ENTRY}

Activation of all TRP channels as nonselective cation channels causes a cell depolarization. This depolarizing action of TRP channels is often underestimated. As outlined, many TRP channels have a relatively small fractional $\mathrm{Ca}^{2+}$ current. TRPV1, the classical example for TRPchannel-activated $\mathrm{Ca}^{2+}$ entry, has only a fractional $\mathrm{Ca}^{2+}$ current of less than 5\% (Zeilhofer et al. 1997). Also, TRPM8 has a small fractional $\mathrm{Ca}^{2+}$ current of $\sim 3 \%$. Only TRPV5, TRPV6, and, in addition, TRPA1 and TRPM 3 are characterized by a high fractional $\mathrm{Ca}^{2+}$ current. For TRPM3, this fraction is around $24 \%$ of the total current and even increases to $~ 51 \%$ in $10 \mathrm{mM}$ $\mathrm{Ca}^{2+}$ (Drews et al. 2010). Therefore, next to their role as $\mathrm{Ca}^{2+}$-entry channels, it has to be considered that TRPs may have an important function as depolarizing ion channels.

First, TRP function concerns excitable cells expressing voltage-operated $\mathrm{Ca}^{2+}$ channels (CaVs, VOCCs) (Fig. 3A). Activation of TRP channels would trigger gating of those channels 
A Depolarizing function of TRPs

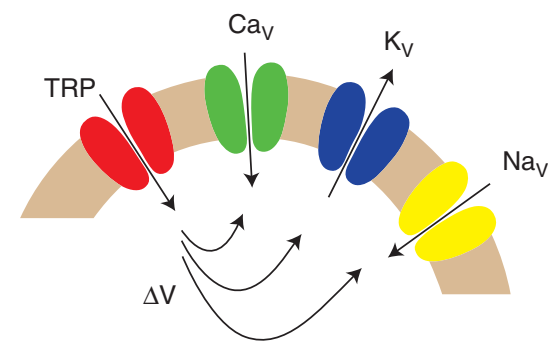

Excitable cell
B TRPs modulate driving forces

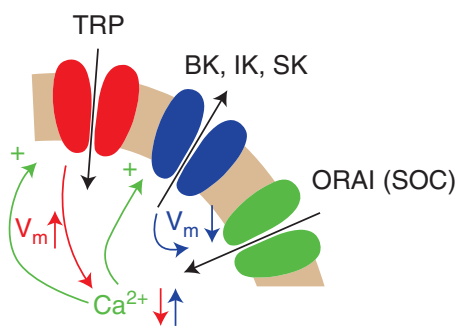

Non-excitable cell

Figure 3. TRP channels depolarize excitable cells and modulate the driving force for $\mathrm{Ca}^{2+}$ entry. (A) Depolarization of excitable cells upon opening of TRP channels regulates voltage-dependent $\mathrm{Ca}^{2+}, \mathrm{K}^{+}$, and $\mathrm{Na}^{+}$channels. (B) Membrane depolarization by TRP channels results in a reduced $\mathrm{Ca}^{2+}$ entry via ORAI, whereas hyperpolarization of the membrane by BK, IK, or SK channels results in an increased $\mathrm{Ca}^{2+}$ influx. This $\mathrm{Ca}^{2+}$ then modulates TRP and BK, IK, and SK function to fine-tune the $\left[\mathrm{Ca}^{2+}\right]_{\mathrm{i}}$ content.

or, if maintained depolarizations are generated, may induce $\mathrm{Ca}^{2+}$-channel inactivation. In addition, the firing pattern of neuronal cells will be modulated by conductance changes via TRP channel activation of inhibition. Examples have been described in detail, indicating that electrogenic effects of TRP channels might be even more important than a direct contribution to $\left[\mathrm{Ca}^{2+}\right]_{\mathrm{i}}$ changes by mediating $\mathrm{Ca}^{2+}$ entry. Only some are mentioned here. All TRPCs are expressed in the brain and obviously have a significant role in regulation of the firing pattern of neurons (Ramsey et al. 2006; Huang et al. 2007; Boisseau et al. 2008; Gokce et al. 2009). They are involved in brain development, synaptogenesis, growth-cone guidance, dendritic growth, spine forming, and many other functions coupled to electrogenesis (Amaral and Pozzo-Miller 2007b; Wen et al. 2007; Tai et al. 2008; for a review, see Talavera et al. 2008; Shim et al. 2009). Persistent neuronal activity lasting seconds to minutes allows the transient storage of memory traces in entorhinal cortex and, thus, could play a major role in working memory. This firing property involves intrinsic properties in cortical neurons by the recruitment of a nonselective cation conductance, probably via heteromeric TRPC channels (TRPC4/5) (Zhang et al. 2010). TRPC3 and
TRPC7 channels are expressed in rhythmically active ventral respiratory group islands in the Pre-Bötzinger complex. TRPC3/7 mediate inward currents underlying the pacemaker activity and enhance respiratory rhythm activity (Ben-Mabrouk and Tryba 2010). TRPC3 in the hippocampus is involved in theta-burst stimulation of mossy fibers (MF). Brief thetaburst stimulation of mossy fibers induced a long-lasting depression in the amplitude of EPSCs mediated by both AMPA and NMDA receptors and a reduction in neurotransmitter release. This depression depends on BDNFmediated activation of TRPC3, and probably has an electrical component (Amaral and Pozzo-Miller 2007a; Li et al. 2010). It has also been shown that TRPV1 mediates long-term depression, including a $\mathrm{Ca}^{2+}$-independent mechanism (Gibson et al. 2008). In general, TRPV1 seems to be involved in the regulation of LTP and LTD (Li et al. 2008). TRPV1 is involved in the activity-dependent facilitation of glutamatergic transmission from solitary tract (ST) afferents. Afferent activation triggered long-lasting asynchronous glutamate release only from TRPV1-expressing synapses, resulting in postsynaptic EPSCs. This release depends on presynaptic TRPV1s and depolarization-dependent activation of 
VOCCs. This interaction provides a new form of synaptic plasticity and brings a new integrative feature to the CNS and autonomic regulation (Peters et al. 2010). Another striking interaction between TRPV1 and VOCC has been shown for the action of TNF- $\alpha$ on nociception, which depends on a TRPV1-induced shift in the membrane potential and a modulation of VOCCs thereupon (mainly N-type, less L- and P-/ Q-type) (Hagenacker et al. 2009). Temperature can dynamically influence the hippocampal neural activities. TRPV4 seems to be an important player in this signaling cascade: Activation of TRPV4 depolarizes the resting membrane potential in hippocampal neurons by allowing cation influx and potentiates neuronal firing. This effect is absent in TRPV4-deficient mice and to evoke firing, larger depolarizations are required in these mice. Thus, TRPV4 is a key regulator for hippocampal neural excitabilities, also a $\mathrm{Ca}^{2+}$-independent mechanism (Shibasaki et al. 2007).

Several functions of TRP channels involved in the generation of pacemaking inward currents are known. In cardiac muscle, TRPCmediated inward currents might participate in pacemaking (Ju and Allen 2007). In ileal smooth muscle cell, TRPC4 underlies the muscarinic inward current, which triggers depolarization and the contractile response of these intestinal muscles (Tsvilovskyy et al. 2009). Many other examples for a close interaction between TRP channels and VOCC can be found in the literature.

Second, TRP channels can regulate the driving forces for $\mathrm{Ca}^{2+}$ entry, mainly in nonexcitable cells, via depolarization (negative-feedback regulation) or hyperpolarization (positive-feedback regulation) via $\mathrm{Ca}^{2+}$-dependent activation of other ion channels, such as $\mathrm{K}^{+}$channels (Fig. 3B). Again, many examples are described in detail. For instance, TRPM4 and TRPM5 are both activated by an increase in $\left[\mathrm{Ca}^{2+}\right]_{\mathrm{i}}$ but are impermeable for $\mathrm{Ca}^{2+}$. They influence, however, $\mathrm{Ca}^{2+}$ entry through $\mathrm{Ca}^{2+}$-permeable channels such as the ORAI/STIM complex (CRAC), by decreasing $\mathrm{Ca}^{2+}$ entry due to depolarization (for a striking negative-feedback example, see mast cells; Nilius and Vennekens
2006; Vennekens et al. 2007). Inhibition of TRPM4 in mast cells causes cell hyperpolarization following antigen activation of these cells. In turn, the CRAC-mediated $\mathrm{Ca}^{2+}$ influx will be increased, resulting in an elevated release of histamine and interleukins and consequently in an aggravated allergic response (Vennekens et al. 2007; Vennekens et al. 2008). Conversely, activation of TRPM4 might be a means to weaken allergic responses. This interaction between depolarizing TRPM4/5 and the hyperpolarization by $\mathrm{Ca}^{2+}$-activated $\mathrm{K}^{+}$channels, such as $\mathrm{BK}_{\mathrm{Ca}}$ (Slo1 or $\mathrm{K}_{\mathrm{Ca}} 1.1, \mathrm{~K}_{\mathrm{Ca}} 4.1-4.2$ ), IKs $\left(\mathrm{K}_{\mathrm{Ca}} 3.1\right)$, and SKs $\left(\mathrm{K}_{\mathrm{Ca}} 2.1-2.3\right)$ generates a fine-tuning of $\mathrm{Ca}^{2+}$ entry in many nonexcitable cells, such as several blood cell types and endothelial cells. Another striking example is the close interaction and physical association of TRPC1 with $\mathrm{BK}_{\mathrm{Ca}}$ in vascular smooth muscle cells. Activation of TRPC1 causes hyperpolarization, which in turn could serve to reduce agonist-induced membrane depolarization, thereby preventing excessive contraction of VSMCs to contractile agonists (Kwan et al. 2009). A similar BKCa-TRPC6 association is considered for the dynamic regulation of the filter slit function in podocytes of the renal glomeruli (Kim et al. 2009a).

Third, TRP channels are targets of changes of $\left[\mathrm{Ca}^{2+}\right]_{\mathrm{i}}$ themselves. They can be activated or inhibited by $\mathrm{Ca}^{2+}$. Probably the earliest $\mathrm{Ca}^{2+}$-activated channel in phylogenies is the yeast mechanosensor TRPY1, in which $\mathrm{Ca}^{2+}$ binds to clusters of negative charges in the $\mathrm{C}$-terminus and greatly enhances the force-induced activation (Su et al. 2009). Other TRP channels that are activated by $\mathrm{Ca}^{2+}$ include TRPC1, TRPC4, TRPC5, TRPC6, TRPV4, TRPM2, TRPA1, TRPM4, and TRPM5. Many, if not all, TRP channels are modulated by $\mathrm{Ca}^{2+}$, often via complex signaling cascades including $\mathrm{Ca}^{2+} / \mathrm{CaM}$ binding, $\mathrm{Ca}^{2+}$-dependent PLC modulation, and $\mathrm{Ca}^{2+}$-dependent PKC activation (for TRPM4, see Nilius et al. 2005b). Some TRPs have more $\mathrm{Ca}^{2+}$-binding sites, often overlapping with PIP2- and especially CaMbinding sites, for which binding domains have been identified in detail for TRPC1 through 7. CaM may also interrupt binding sites for 
many proteins such as MARCKS, GAP43, GRK5, EGFR, and the ErbB family (for a review, see Gordon-Shaag et al. 2008). In addition to $\mathrm{Ca}^{2+}$-dependent activation, all TRP channels show an activity-dependent inactivation mediated by $\mathrm{Ca}^{2+}$, mostly at higher concentrations than needed for activation. Possible mechanisms include $\mathrm{Ca}^{2+}$-dependent kinases; $\mathrm{Ca}^{2+}{ }_{-}$ dependent phosphatases; $\mathrm{Ca}^{2+}$-regulated PLCs, which modulate the important TRP-channel modulator $\mathrm{PI}(4,5) \mathrm{P}_{2}$ (Nilius et al. 2006); and direct interaction with $\mathrm{Ca}^{2+} / \mathrm{CaM}$ (Nilius et al. 2005b; Gordon-Shaag et al. 2008; Nilius et al. 2008). This interplay between $\mathrm{Ca}^{2+}$ dependent activation and inactivation provides a huge diversity of TRP-channel modulation in native cells.

\section{TRP CHANNELS AS INTRACELLULAR CALCIUM-RELEASE CHANNELS}

The main dogma so far has been that most of the TRP channels exert their functional effects by their strategic localization in the plasma membrane, where they act as ion channels. Their role as scaffolding proteins or intracellular proteins serving different cell functions has not yet been considered systematically. In fact, most, if not all, TRP channels are also located in intracellular organelles, in which the sarco/endoplasmic reticulum and endosomes, lysosomes, and autophagosomes are only the best-studied compartments. The role of mitochondrial-, Golgi-, nuclear- and peroxisomal-TRP channels is not yet understood. TRP channels can be found in intracellular membranes that form part of the biosynthetic or secretory pathway, mainly, when they are on the way to the plasma membrane. Alternatively, TRP channels may play a role in intracellular organelles, participating in maintaining/establishing vesicular ion homeostasis or regulating membrane trafficking. Following the division of intracellular organelles into two groups (group 1: endocytotic, secretory, and autophagic with ER, Golgi apparatus, secretory vesicles/granules, endosomes, autophagosomes, and lysosomes; and group 2: mitochondria, peroxisomes, and nucleus), all have intraluminal- $\mathrm{Ca}^{2+}$ concentrations much higher than the cytosolic- $\mathrm{Ca}^{2+}$ concentrations, ranging from $\mu \mathrm{M}$ to $\mathrm{mM}$ (Dong et al. 2010). Therefore, $\mathrm{Ca}^{2+}$ homeostasis in these organelles will be a crucial cell function. Increasing evidence points to a role of several TRP channels as intracellular, calcium-release channels, which is the focus of this review. An important problem is that many TRP channels, as discussed above, require $\mathrm{PI}(4,5) \mathrm{P}_{2}$ for activation (see Rohacs 2007; Rohacs and Nilius 2007; Nilius et al. 2008; Rohacs 2009). Because intracellular membranes lack this phospholipid, it is intriguing to speculate that other substituents may compensate for the requirement of $\mathrm{PI}(4,5) \mathrm{P}_{2}$ for TRP functioning (Fig. 4).

\section{TRP Channels in Endoplasmic and Sarcoplasmic Reticulum}

First, evidence for a role for TRPV1 as an intracellular, calcium-release channel comes from experiments showing that activation of heterologously expressed TRPV1 in COS-7 cells and native TRPV1 in dorsal root ganglion cells gives rise to an increase in intracellular calcium in the absence of extracellular calcium (Olah et al. 2001). It was also already known that a weak agonist of TRPV1, anandamide, induces intracellular calcium release via a PLC-independent mechanism (Felder et al. 1993). Further experiments revealed that TRPV1 is localized to the ER and Golgi compartments. Activation of TRPV1 by capsaicin induces calcium release from an $\mathrm{IP}_{3}$-sensitive but thapsigargin-insensitive store (Turner et al. 2003). Calcium gradients in the Golgi are maintained by SERCA and by the thapsigargin-insensitive secretory pathway (SPCA). Intracellular stores can be dissected based on their release and/or refilling capacities; within the $\mathrm{IP}_{3}$-sensitive store, there exists a compartment that also contains functional TRPV1 molecules that mediate release. The TRPV1/IP 3 R-containing store is apparently thapsigargin-insensitive. Depletion of this calcium store can occur without $\mathrm{I}_{\mathrm{CRAC}}$ activation. Due to the thapsigargin-insensitivity of TRPV1-induced calcium release, the most likely location for TRPV1 is in the SPCA-positive 


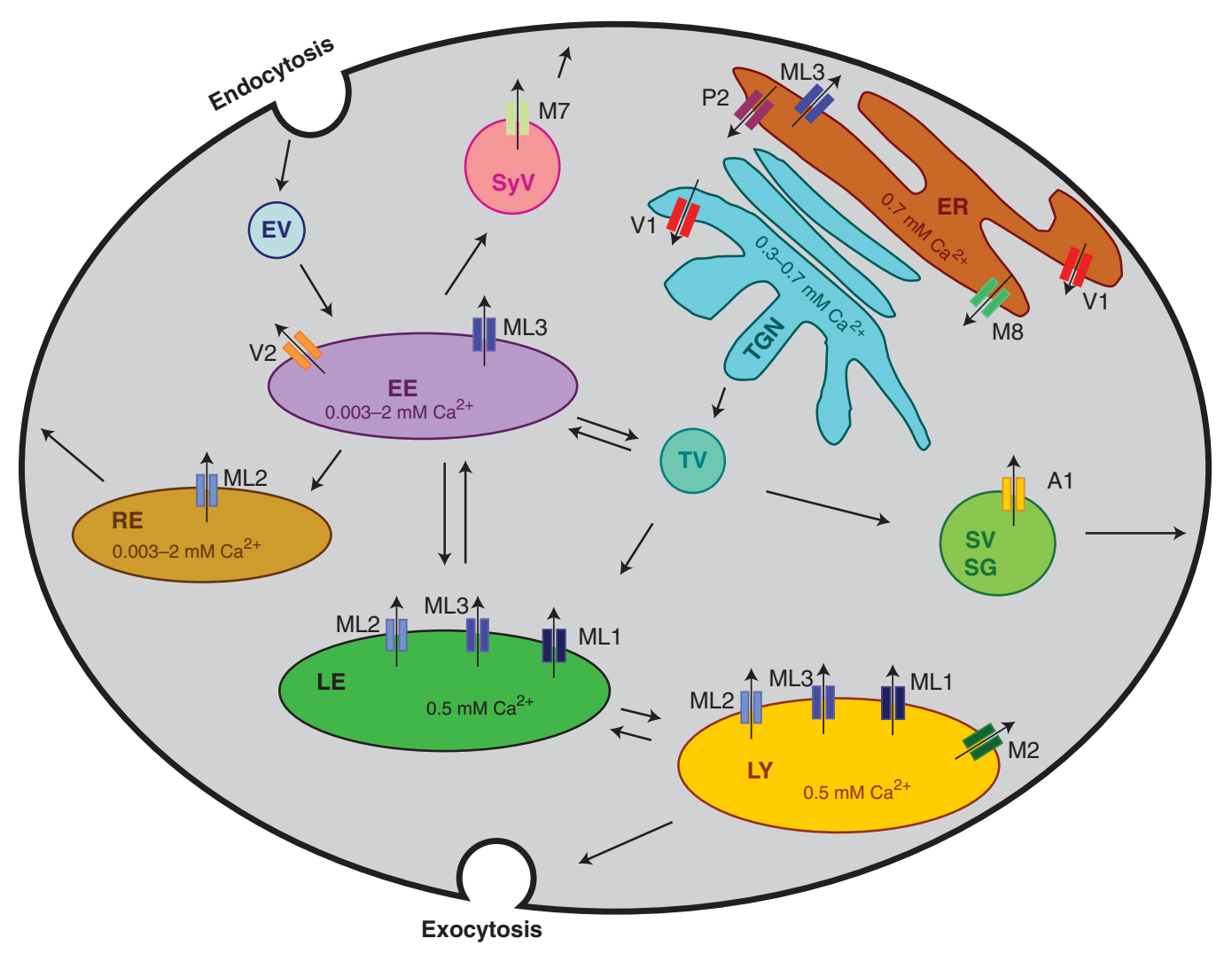

Figure 4. Expression of TRP channels in intracellular compartments. Early endosomes (EE) are derived from the plasma membrane via endocytotic vesicles (EV). The cargo from these early endosomes can either go back to the plasma membrane via the recycling endosomes (RE) or follow the late endocytotic pathway via late endosomes (LE) to the lysosomes (LY). Intermediate transport vesicles (TV) are derived from the ER and/or the trans-Golgi-network (TGN). The content in these transport vesicles can either be delivered to early endosomes, late endosomes, or be transported to the plasma membrane via secretory vesicles (SV) or secretory granules (SG). Synaptic vesicles (SyV) are derived from early endosomes and release neurotransmitters in the extracellular space. Only intracellular locations of TRP channels are indicated.

Golgi compartments (Turner et al. 2003). However, other studies suggest that TRPV1- and thapsigargin-sensitive internal calcium pools substantially overlap, and that TRPV1 immunoreactivity co-localizes with a marker in the ER. Still, although TRPV1 forms agonist-sensitive channels in the ER, which upon activation release calcium from internal stores, it fails to activate endogenous store-operated $\mathrm{Ca}^{2+}$ entry (Wisnoskey et al. 2003).

TRPM8 is amongst others expressed in LNCaP (lymph node carcinoma of the prostate) cells and sensory neurons from dorsal root and trigeminal ganglia (McKemy et al. 2002; Zhang and Barritt 2004; Thebault et al. 2005; Ramsey et al. 2006). Several lines of evidence suggest that TRPM8 is involved in menthol-induced calcium release from intracellular stores. TRPM8 is shown to be expressed in both the endoplasmic reticulum and the plasma membrane of the androgen-responsive prostate cancer LNCaP cells and to mediate, respectively, $\mathrm{Ca}^{2+}$ inflow and $\mathrm{Ca}^{2+}$ release from intracellular stores in these cells (Zhang and Barritt 2004). These cells show a current in response to cold and menthol with biophysical properties (strong inward rectification and high calcium selectivity) different than those described for 
TRPM8 in a heterologous expression system and in sensory neurons (Thebault et al. 2005). This current could nevertheless be suppressed by experimental maneuvers that decrease endogenous TRPM8 mRNA or protein, which is explained by the extraplasmalemmal localization of TRPM8 in these cells. Indeed, TRPM8 in the ER from LNCaP cells is able to support $\mathrm{Ca}^{2+}$ release in response to cold or menthol, and this $\mathrm{ER} \mathrm{Ca}^{2+}$ store depletion activates $\mathrm{Ca}^{2+}$ entry via plasma membrane store-operated channels (SOC) (Thebault et al. 2005). However, the fact that TRPM8 is responsible for the menthol-induced calcium release is controversial. Indeed, experiments in different cell lines (HEK293, LNCaP, CHO, and COS cells) indicate that the menthol-induced calcium release is potentiated at higher temperatures (Mahieu et al. 2007). Furthermore, overexpression of TRPM8 does not enhance the menthol-induced calcium release; icilin and eucalyptol, 2 more potent agonists of TRPM8 than menthol, do not induce calcium release, unlike geraniol and linalool, which are structurally related to menthol. These data indicate that menthol induces intracellular calcium release in a TRPM8-independent manner. Clearly, more experiments are needed to unravel the molecular identity of this calcium-release channel.

$\operatorname{Trpp} 2$ and $P k d 1$, or polycystin-1, are genes mutated in autosomal-dominant polycystic kidney disease (ADPKD). Both proteins are expressed in many tissues, including kidney, heart, liver, pancreas, brain, and muscles (Hughes et al. 1995; Geng et al. 1997; Luo et al. 2003). PKD1 is a large glycoprotein localized to the plasma membrane and primary cilia (Hanaoka et al. 2000; Newby et al. 2002; Yoder et al. 2002). TRPP2 has a dynamic expression pattern with localization reported in mitotic spindles, the ER/SR, basolateral plasma membrane, and together with PKD1 in the primary cilium (Cai et al. 1999; Foggensteiner et al. 2000; Yoder et al. 2002; Rundle et al. 2004). Expression of TRPP2 in the ER is caused by ER-retention signals in the cytoplasmic tail, which will prevent trafficking of TRPP2 toward the plasma membrane (Cai et al. 1999; Hanaoka et al. 2000). Masking or deleting this ER-retention motif allows plasma membrane expression of TRPP2 (Cai et al. 1999). Co-immunoprecipitation experiments show that polycystin-1, which is present at the plasma membrane, is physically associating with polycystin-2 (Tsiokas et al. 1997). This might mean that TRPP2 can function as a surface membrane calciumpermeable channel or signaling complex, chaperoned by TRPP1 (Hanaoka et al. 2000). On the other side, TRPP2 may be located in the $\mathrm{ER}$, tethering close to the surface membrane via the physical association with TRPP1 (Koulen et al. 2002). Single channel recordings from ER microsomes fused to lipid bilayers reveal that polycystin-2 is a high conductance channel that is permeable to divalent cations (Koulen et al. 2002). It functions as a calciumrelease channel in a porcine kidney cell line (LLC-PK1) to augment calcium transients initiated by the $\mathrm{IP}_{3}$ receptor after receptor stimulation by, for example, vasopressin. This calcium release does not seem to require coassembly with polycystin-1. Cells expressing a mutant channel protein, which retains the protein interactions with wild-type polycystin-2, do not show this calcium release, strongly indicating that TRPP2 itself forms the channel (Koulen et al. 2002), in contrast with the polycystin1-dependent channel activity of TRPP2 at the plasma membrane (Hanaoka et al. 2000). TRPP2 can be activated by intracellular calcium; it shows a bell-shaped response curve to $\mathrm{Ca}^{2+}$ that is dependent on phosphorylation at the C-terminus of the protein (Cai et al. 2004). These data suggest that TRPP2 functions as a new type of calcium-release channel, with properties (ER location, calcium-dependent calcium-channel activity) allowing it to mediate calcium-induced calcium release. Recent data suggest that the function of TRPP2 as a calcium-induced calcium-release channel is dependent on interaction with the $\mathrm{IP}_{3}$ receptor, and that TRPP2 is activated by a local rise in cytosolic $\mathrm{Ca}^{2+}$ generated by $\mathrm{IP}_{3}$-induced calcium release (Sammels et al. 2010). The pathomechanism by which the TRPP2 channel, together with PKD1, contributes to ADPKD is still not completely understood. In the primary 
cilium, the TRPP2/PKD1 complex acts as a mechanosensor that provides flow-activated $\mathrm{Ca}^{2+}$ entry and plays a role in $\mathrm{Ca}^{2+}$ signaling in tubular renal cells. This mechanosensitive property of the complex is deficient in PKD1deficient cells. Additionally, the PKD1/TRPP2 complex regulates transfer of the helix-loophelix (HLH) protein Id2, a crucial regulator of cell proliferation and differentiation, into the nucleus. An enhanced nuclear localization of Id 2 in renal epithelial cells from AKPKD patients constitutes a mechanism for the hyperproliferative phenotype and may cause cyst formation (Benezra 2005; Li et al. 2005). Furthermore, TRPP2 may play a role in the increased apoptotic rate reported in $\mathrm{ADPKD}$ patients and several models of polycystic kidney diseases. Indeed, the $\mathrm{Ca}^{2+}$ content of the ER determines the sensitivity of the cell to apoptotic stress, and TRPP2 is suggested to function as an antiapoptotic ion channel that regulates the $\mathrm{Ca}^{2+}$ concentration in the ER (Wegierski et al. 2009).

TRP Channels in Endosomes and Lysosomes

The endolysosome system is comprised of early endosomes, recycling endosomes, late endosomes, and lysosomes (Luzio et al. 2007b; Dong et al. 2010). Early endosomes are derived from the plasma membrane via endocytosis. Components in these early endosomes can either be recycled back to the plasma membrane via the recycling endosomes or follow the late endosome pathway. Lysosomes are derived from late endosomes and are filled with hydrolytic enzymes. Some common features of endolysosomes are an acidic $\mathrm{pH}$ (established and maintained by the vacuolar (V)-ATPase $\mathrm{H}^{+}$ pump and essential for the degradative function of the hydrolases) and a positive membrane potential (assumed to be in the range of +30 to $+110 \mathrm{mV}$ ) that provides a driving force for calcium release into the cytosol. Indeed, endolysosomes also serve as storage for intracellular calcium, containing a luminal calcium concentration of $\sim 0.5 \mathrm{mM}$ that is maintained by an unidentified $\mathrm{H}^{+}-\mathrm{Ca}^{2+}$ exchanger. Next to other factors, such as small GTPase Rabs and phosphoinositides (PIP), membrane trafficking is regulated by the release of calcium from endolysosomes. In fact, the membrane fusion process that drives the movement of endocytosed material and enzymes within the endocytic pathway depends on calcium ions, presumably released from the endocytic organelles (Pryor et al. 2000). However, the ion channels responsible for endolysosomal calcium release are still undefined. Candidates include several members of the TRP family, such as TRPMLs, TRPV2, and TRPM2.

TRPMLs, or mucolipins, constitute a family of inwardly-rectifying, calcium-permeant, but probably proton-impermeant, cation channels and consist of three members: TRPML1, TRPML2, and TRPML3. All TRPMLs colocalize with lysosome-associated membrane protein (Lamp-1) or Rab7, indicating localization to late endosomes and lysosomes (Karacsonyi et al. 2007; Thompson et al. 2007; Kim et al. 2009b; Martina et al. 2009). In addition, TRPML2 is found in recycling endosomes (Karacsonyi et al. 2007), whereas TRPML3 also localizes to early endosomes and the plasma membrane (Kim et al. 2009b). However, it has been shown that TRPMLs interact to form homo- and heteromultimers, and that the presence of either TRPML1 or TRPML2 specifically influences the spatial distribution of TRPML3. Indeed, TRPML1 and TRPML2 homomultimers form lysosomal proteins, whereas TRPML3 homomultimers are probably channels in the endoplasmic reticulum. However, TRPML3 localizes to lysosomes when coexpressed with either TRPML1 or TRPML2, and is comparably mislocalized when lysosomal targeting of TRPML1 and TRPML2 is disrupted. Conversely, TRPML3 does not cause retention of TRPML1 or TRPML2 in the endoplasmic reticulum. These data demonstrate that there is a hierarchy controlling the subcellular distributions of the TRPMLs, such that TRPML1 and TRPML2 dictate the localization of TRPML3 and not vice versa (Venkatachalam et al. 2006).

TRPML1 (or Mucolipin 1) is the best described member of the TRPML subfamily and is expressed in almost every tissue with the highest level of expression in the brain, kidney, 
spleen, liver, and heart (Sun et al. 2000). TRPML1 follows a direct or indirect pathway to reach lysosomes. Newly synthesized proteins, together with TRPML1, are routed directly from the Golgi to lysosomes by recognition of the N-terminal $\mathrm{E}^{11}$ TERLLL motif of TRPML1 (direct pathway). The indirect pathway comprises trafficking to the plasma membrane, followed by internalization to early endosome that is guided by the C-terminal $\mathrm{E}^{573} \mathrm{EHSLL}$ motif (Curcio-Morelli et al. 2009; Samie et al. 2009). TRPML1 is a TRP-channel-related protein that shows strong topological homology with the polycystin-2 channel and contains an internal $\mathrm{Ca}^{2+}$ - and $\mathrm{Na}^{+}$-channel-pore region (Sun et al. 2000). Several studies suggest that TRPML1 is a nonselective cation channel with a large conductance and permeability to $\mathrm{Na}^{+}$, $\mathrm{K}^{+}$, and $\mathrm{Ca}^{2+}$ (LaPlante et al. 2002; Raychowdhury et al. 2004). However, its localization in the endolysosomal membrane makes it difficult to characterize. TRPML3 is the only TRPML channel found in the plasma membrane, making it easier to characterize the channel properties via whole-cell current measurements. This revealed that TRPML3 is an inwardly rectifying, $\mathrm{Ca}^{2+}$-permeable cation channel (Cuajungco and Samie 2008). The current is inhibited by an acid extracytosolic (analogous to the luminal side) $\mathrm{pH}$ (Kim et al. 2008). Notably, elimination of TRPML3 regulation by extracytosolic $\mathrm{pH}$ has the same functional and cellular phenotype as the A419P (Va) mutation, a gain-of-function mutation that causes the varitint-waddler phenotype (a disease characterized by deafness, circling behavior, and pigmentation defects) (Di Palma et al. 2002). This mutation is likely to disrupt channel-gating by locking the channel in an open state, making the channel constitutively active and yielding much larger currents (Cuajungco and Samie 2008); although basic properties, such as I-V characteristics, single channel conductance, and ion selectivity have not changed (Kim et al. 2007; Nagata et al. 2008). The same mutation has been made in TRPML1 and TRPML2 channels in order to effectively characterize the pore properties of these channels using whole-cell recordings. This revealed, for both channels, inwardly rectifying, $\mathrm{Ca}^{2+}$-permeable cation currents, in accordance with TRPML3 channel properties (Dong et al. 2009; Samie et al. 2009). At least for TRPML1, several properties of this mutated channel, such as IV relationship, kinetics, and voltage dependence, are similar to the wild-type channel measured in the lysosomal membrane (Dong et al. 2008), indicating that the activating Va mutation is a useful approach for characterizing the pore properties of TRPML1. Obviously, these channels provide a novel class of TRP channels that are functionally still much less characterized than other TRPs ( for an excellent review, see Cheng et al. 2010b; Dong et al. 2010).

The physiological functions of the TRPML channels are still under intensive investigation. Mucolipins could regulate the ionic conditions within, and acidity of, the endocytic organelles, in this way regulating the activity and delivery of the digestive enzymes within the endocytic pathway (Puertollano and Kiselyov 2009). However, the calcium permeability of TRPML channels allows a role in different intracellular processes regulated by calcium. Mutations in the Trpml1 gene cause mucolipidosis type IV, a lysosomal storage disease characterized by severe psychomotor retardation and ophthalmologic abnormalities. Indeed, all cell types show an abnormal accumulation of phospholipids, sphingolipids, acidic mucopholysaccharides, and cholesterol in swollen and enlarged LEL-like vacuoles (Puertollano and Kiselyov 2009). In agreement with this, cells from Trpml1 KO mice show abnormal lipid accumulation and enlarged vacuoles (Venugopal et al. 2007). These enlarged LELs seem to be the late endosome-lysosome hybrid organelles from which lysosomes are formed in the normal situation. Enlarged endolysosomes can result from either uncontrolled and excessive fusion, defective membrane fission, or impaired organellar osmoregulation (Luzio et al. 2007a). The defect observed in Trpmll-deficient cells is most likely related to the sorting and trafficking processes of the endocytic pathway, more specifically the formation of transport vesicles from the LEL compartment to the trans-Golgi-network and the reformation of lysosomes from the late 
endosome-lysosome hybrid organelles (Thompson et al. 2007). The $\mathrm{Ca}^{2+}$ permeability of TRPML1 seems to be required for the membrane fission from LEL compartments or late endosome-lysosome hybrids and the biogenesis of both late retrograde transport vesicles and lysosomes. Indeed, membrane fission and stabilization of transport vesicles are dependent on luminal calcium and intraluminal calcium release (Luzio et al. 2007a). The major mucolipidosis type IV disease mutations of TRPML1 are expected to produce no protein (Altarescu et al. 2002). However, two mutations (V446L and $\triangle F 408)$ do retain TRPML1 channel function. WT TRPML1 is inhibited by a reduction of $\mathrm{pH}$, and this $\mathrm{pH}$-dependent regulation seems to be lost in these two mutations (Raychowdhury et al. 2004). The recent generation of the Trpml1 KO mouse, a murine model for MLIV, will help to further elucidate the function of TRPML1 (Venugopal et al. 2007). Interestingly, a Drosophila model for mucolipidosis type IV has been developed that mimicks some of the key disease features, such as abnormal intracellular accumulation of macromolecules, motor defects, and neurodegeneration. Here, the basis for macromolecule retention is a defective autophagy, which results in oxidative stress and impaired synaptic transmission. Late-apoptotic cells accumulate in the brains of trpml- (the only TRPML member in the fly) deficient flies. The accumulation of those cells, and also the degree of motor deficits, were suppressed by expression of TRPML in neurons, glia, and hematopoietic cells. Because hematopoietic cells in humans are involved in clearance of apoptotic cells, it seems possible that bone marrow transplantation might have a potential as a new therapeutic strategy for MLIV (Venkatachalam et al. 2008).

TRPML1 is also thought to mediate a NAADP-activated intracellular calcium release channel. Indeed, nicotinic acid adenine dinucleotide phosphate (NAADP) is an attractive candidate for mediating endolysosomal calcium release (Churchill et al. 2002; Calcraft et al. 2009). In fact, a lysosomal NAADP-sensitive $\mathrm{Ca}^{2+}$-release channel, different from sarcoplasmic reticulum $\mathrm{Ca}^{2+}$-release channels, could be measured in lysosomes from native rat liver cells and bovine coronary arterial myocytes (Zhang and Li 2007; Zhang et al. 2009). This current could be blocked by using an antiTRPML1 antibody or a TRPML1-specific siRNA, suggesting involvement of TRPML1. However, the molecular identity of the NAADP receptor remains controversial (Galione and Churchill 2002). Another attractive family of ion channels comprises the two-pore channel family (TPCs) (Patel et al. 2010). Indeed, these channels provide a family of NAADP receptors, with TPC1 and TPC3 being expressed on endolysosomal and TPC2 on lysosomal membranes (Calcraft et al. 2009). Both TPC1 and TPC2 have been shown to be an important component of NAADP-elicited calcium release (Brailoiu et al. 2009; Zong et al. 2009). Thus, the nature of the NAADP-receptor and the contribution of different ion channels to NAADP action remains a matter of debate.

Much less is known about the function of TRPML2 and TRPML3. TRPML2 is expressed in B-lymphocytes at different cell stages. Overexpression of TRPML2 in these cells induces accumulation of enlarged lysosomal structures, indicating that TRPML2 might participate in the regulation of the specialized lysosomal compartment of B-lymphocytes, and in this way may be critical for normal immune response (Song et al. 2006). Furthermore, TRPML2 has been reported to have a regulatory role in the trafficking of proteins along the Arf6-regulated pathway. Indeed, TRPML2 colocalizes with glycosylphosphatidylinositol-anchored proteins (GPI-APs), such as CD59, and overexpression of a TRPML2 inactive mutant decreases recycling of CD59 to the plasma membrane, indicating that TRPML2 localizes to the Arf6-regulated pathway and regulates sorting of GPI-APs (Karacsonyi et al. 2007). Overexpression of TRPML3 leads to reduced constitutive and regulated endocytosis, increased autophagy, and marked exacerbation of autophagy evoked by various cell stressors with nearly complete recruitment of TRPML3 into the autophagosomes (Kim et al. 2009b). These data indicate that TRPML3 is a prominent regulator of endocytosis, membrane trafficking, and autophagy, perhaps by 
controlling the $\mathrm{Ca}^{2+}$ in the vicinity of cellular organelles that is necessary to regulate these cellular events (Kim et al. 2009b). Furthermore, calcium release from endolysosomes by TRPML3 may be important for efficient endosomal acidification. Indeed, after internalization from the plasma membrane, the endosomes contain a high concentration of calcium that is rapidly released in order to allow acidification of the compartment. TRPML3 is a good candidate to mediate this efflux, since the channel is inhibited by low $\mathrm{pH}$ and would still be active at the characteristic $\mathrm{pH}$ of the early endosomes, but will become inactive once the acidification has taken place, in this way preventing further $\mathrm{Ca}^{2+}$ efflux and acidification (Martina et al. 2009). Given the clinical importance of TRPMLs, these channels obviously define a new group of pharmacological targets as introduced recently by small molecule activators of TRPML3 (Grimm et al. 2010).

TRPV2 localizes to early endosomes, and activation of TRPV2 in these intracellular vesicles is suggested to cause calcium-dependent fusion between endosomal membranes (Saito et al. 2007). Endogenous ionic currents measured in an isolated enlarged endosome showed pharmacological similarities (inhibition by Ruthenium Red and activation by 2 aminoethyldiphenyl borate) with the TRPV2 channel. This current was inhibited by a decrease in the luminal $\mathrm{pH}$ and an increase in the luminal chloride concentration, two features known to occur after endocytosis (Saito et al. 2007). The current hypothesis is that activation of TRPV2 leads to $\mathrm{Ca}^{2+}$-dependent fusion between endosomal membranes. Further experiments are needed to confirm this theory.

TRPM2 serves a dual role as a plasma membrane $\mathrm{Ca}^{2+}$-influx channel and as an intracellular, calcium-release channel in pancreatic beta cells (Lange et al. 2009). Indeed, intracellular ADPR elicits intracellular calcium release in these cells, which is dependent on TRPM2 channels and comes from lysosomes. The lysosomal calcium release through TRPM2 contributes to $\mathrm{H}_{2} \mathrm{O}_{2}$-mediated beta cell death (Lange et al. 2009).
TRP Channels in Secretory Vesicles, Secretory Granules, and Synaptic Vesicle

Much less is known about TRP channels in these compartments. TRPA1 is expressed in secretory vesicles and granules (Dong et al. 2010). Icilin, a TRPA1 agonist, elicits intracellular $\mathrm{Ca}^{2+}$ release from secretory vesicles in HEK cells heterologously expressing TRPA1 (Prasad et al. 2008). TRPAl is a $\mathrm{Ca}^{2+}$-activated channel (Zurborg et al. 2007) and may therefore contribute to $\mathrm{Ca}^{2+}$ release from these organelles. TRPM7 is localized in synaptic vesicles of sympathetic neurons and bound to several proteins of the synaptic vesicle fusion apparatus, including synapsin I and synaptotagmin I. Furthermore, ion conductance via TRPM7 is critical to neurotransmitter release upon an increase in $\left[\mathrm{Ca}^{2+}\right]_{\mathrm{i}}$ and might in this way play a role in forming the exocytotic machinery (Krapivinsky et al. 2006). Finally, the role of TRP channels in intracellular organelles is a just-appearing and extremely challenging topic.

\section{CONCLUSIONS}

TRP channels have been extensively reviewed in the last 10 years. It is obvious now that they function not only as polymodal cell sensors in sensory processes, but that they are unique channels involved in many cell functions. We want to stress in this review that TRP channels are not only important for $\mathrm{Ca}^{2+}$ entry via the plasma membrane. This function might even be overestimated, given the often very small fractional $\mathrm{Ca}^{2+}$ currents through these channels. They obviously play an important role in electrogenesis, regulating the activity for voltage-dependent ion channels including $\mathrm{Ca}^{2+}$ channels $\left(\mathrm{Ca}_{\mathrm{V}}\right.$ 's, VOCCs). They are also important regulators of the driving forces for $\mathrm{Ca}^{2+}$ entry via other $\mathrm{Ca}^{2+}$-permeable channels such as ORAIs, CNG, and NMDA receptors. TRPs must also be considered as targets of changes in $\left[\mathrm{Ca}^{2+}\right]_{\mathrm{I}}$, which again creates a huge diversity and versatility of these channels in the whole process of $\mathrm{Ca}^{2+}$ signaling. Finally, TRPs are intracellular channels, and may even act in some cases as scaffolding proteins forming signaling complexes. Their role as intracellular 
channels is just emerging and will undoubtedly be the focus of future research.

\section{ACKNOWLEDGMENTS}

We are grateful to all members of the Laboratory for Ion Channel Research, KU Leuven, for helpful comments and discussion. M.G. was supported by a Doctoral Fellowship of the Research Foundation-Flanders. This work was supported by grants from Interuniversity Attraction Poles Programme - Belgian State - Belgian Science Policy, P6/28, the Research Foundation-Flanders (G.0172.03 and G.0565.07), the Research Council of the KU Leuven (GOA 2004/07), and the Flemish Government (Excellentiefinanciering, EF/95/010). MG and BC contributed equally to this work.

\section{REFERENCES}

Aarts M, Iihara K, Wei WL, Xiong ZG, Arundine M, Cerwinski W, MacDonald JF, Tymianski M. 2003. A key role for TRPM7 channels in anoxic neuronal death. Cell 115: $863-877$.

Aarts MM, Tymianski M. 2005. TRPM7 and ischemic CNS injury. Neuroscientist 11: 116-123.

Ahmmed GU, Malik AB. 2005. Functional role of TRPC channels in the regulation of endothelial permeability. Pflugers Arch 451: 131-142.

Alessandri-Haber N, Yeh JJ, Boyd AE, Parada CA, Chen X, Reichling DB, Levine JD. 2003. Hypotonicity induces TRPV4-mediated nociception in rat. Neuron 39: 497-511.

Altarescu G, Sun M, Moore DF, Smith JA, Wiggs EA, Solomon BI, Patronas NJ, Frei KP, Gupta S, Kaneski CR, et al. 2002. The neurogenetics of mucolipidosis type IV. Neurology 59: 306-313.

Amaral MD, Pozzo-Miller L. 2007a. BDNF Induces Calcium Elevations Associated with IBDNF, a Non-Selective Cationic Current Mediated by TRPC Channels. J Neurophysiol 98: 2476-2482.

Amaral MD, Pozzo-Miller L. 2007b. TRPC3 channels are necessary for brain-derived neurotrophic factor to activate a nonselective cationic current and to induce dendritic spine formation. J Neurosci 27: 5179-5189.

Ambudkar IS, Ong HL, Liu X, Bandyopadhyay BC, Cheng KT. 2007. TRPC1: the link between functionally distinct store-operated calcium channels. Cell Calcium 42: 213-223.

Andre E, Gatti R, Trevisani M, Preti D, Baraldi PG, Patacchini R, Geppetti P. 2009. Transient receptor potential ankyrin receptor 1 is a novel target for pro-tussive agents. Br J Pharmacol 158: 1621-1628.

Asakawa M, Yoshioka T, Matsutani T, Hikita I, Suzuki M, Oshima I, Tsukahara K, Arimura A, Horikawa T,
Hirasawa T, et al. 2006. Association of a mutation in TRPV3 with defective hair growth in rodents. J Invest Dermatol 126: 2664-2672.

Audo I, Kohl S, Leroy BP, Munier FL, Guillonneau X, Mohand-Said S, Bujakowska K, Nandrot EF, Lorenz B, Preising M, et al. 2009. TRPM1 is mutated in patients with autosomal-recessive complete congenital stationary night blindness. Am J Hum Genet 85: 720-729.

Authi KS. 2007. TRP channels in platelet function. Handb Exp Pharmacol 179: 425-443.

Bautista DM, Jordt SE, Nikai T, Tsuruda PR, Read AJ, Poblete J, Yamoah EN, Basbaum AI, Julius D. 2006. TRPA1 mediates the inflammatory actions of environmental irritants and proalgesic agents. Cell 124: 1269-1282.

Beech DJ. 2005. Emerging functions of 10 types of TRP cationic channel in vascular smooth muscle. Clin Exp Pharmacol Physiol 32: 597-603.

Beech DJ, Muraki K, Flemming R. 2004. Non-selective cationic channels of smooth muscle and the mammalian homologues of Drosophila TRP. J Physiol 559: 685-706.

Benezra R. 2005. Polycystins: inhibiting the inhibitors. Nat Cell Biol 7: 1064-1065.

Ben-Mabrouk F, Tryba AK. 2010. Substance P modulation of TRPC3/ 7 channels improves respiratory rhythm regularity and ICAN-dependent pacemaker activity. Eur J Neurosci 31: 1219-1232.

Berridge MJ, Lipp P, Bootman MD. 2000. The versatility and universality of calcium signalling. Nat Rev Mol Cell Biol 1: $11-21$.

Bezzerides VJ, Ramsey IS, Kotecha S, Greka A, Clapham DE. 2004. Rapid vesicular translocation and insertion of TRP channels. Nat Cell Biol 6: 709-720.

Birnbaumer L. 2009. The TRPC class of ion channels: a critical review of their roles in slow, sustained increases in intracellular $\mathrm{Ca}(2+)$ concentrations. Annu Rev Pharmacol Toxicol 49: 395-426.

Birrell MA, Belvisi MG, Grace M, Sadofsky L, Faruqi S, Hele DJ, Maher SA, Freund-Michel V, Morice AH. 2009. TRPA1 agonists evoke coughing in guinea pig and human volunteers. Am J Respir Crit Care Med 180: 1042-1047.

Bisgrove BW, Snarr BS, Emrazian A, Yost HJ. 2005. Polaris and Polycystin- 2 in dorsal forerunner cells and Kupffer's vesicle are required for specification of the zebrafish leftright axis. Dev Biol 287: 274-288.

Boisseau S, Kunert-Keil C, Lucke S, Bouron A. 2008. Heterogeneous distribution of TRPC proteins in the embryonic cortex. Histochem Cell Biol 131: 355-363.

Bolotina VM. 2008. Orai, STIM1 and iPLA2beta: a view from a different perspective. J Physiol 586: 3035-3042.

Bootman MD, Collins TJ, Peppiatt CM, Prothero LS, MacKenzie L, De Smet P, Travers M, Tovey SC, Seo JT, Berridge MJ, et al. 2001. Calcium signalling-an overview. Semin Cell Dev Biol 12: 3-10.

Brailoiu E, Churamani D, Cai X, Schrlau MG, Brailoiu GC, Gao X, Hooper R, Boulware MJ, Dun NJ, Marchant JS, et al. 2009. Essential requirement for two-pore channel 1 in NAADP-mediated calcium signaling. J Cell Biol 186: $201-209$. 
Cai X. 2008. Unicellular $\mathrm{Ca}^{2+}$ Signaling 'Toolkit' at the Origin of Metazoa. Mol Biol Evol 25: 1357-1361.

Cai Y, Anyatonwu G, Okuhara D, Lee KB, Yu Z, Onoe T, Mei CL, Qian Q, Geng L, Wiztgall R, et al. 2004. Calcium dependence of polycystin-2 channel activity is modulated by phosphorylation at Ser812. J Biol Chem 279: 19987-19995.

Cai Y, Maeda Y, Cedzich A, Torres VE, Wu G, Hayashi T, Mochizuki T, Park JH, Witzgall R, Somlo S. 1999. Identification and characterization of polycystin-2, the PKD2 gene product. J Biol Chem 274: 28557-28565.

Calcraft PJ, Ruas M, Pan Z, Cheng X, Arredouani A, Hao X, Tang J, Rietdorf K, Teboul L, Chuang KT, et al. 2009. NAADP mobilizes calcium from acidic organelles through two-pore channels. Nature 459: 596-600.

Caterina MJ, Rosen TA, Tominaga M, Brake AJ, Julius D. 1999. A capsaicin-receptor homologue with a high threshold for noxious heat. Nature 398: 436-441.

Caterina MJ, Schumacher MA, Tominaga M, Rosen TA, Levine JD, Julius D. 1997. The capsaicin receptor: a heat-activated ion channel in the pain pathway. Nature 389: 816-824.

Chang Y, Schlenstedt G, Flockerzi V, Beck A. 2010. Properties of the intracellular transient receptor potential (TRP) channel in yeast, Yvc1. FEBS Lett 584: 2028-2032.

Charrua A, Cruz CD, Cruz F, Avelino A. 2007. Transient receptor potential vanilloid subfamily 1 is essential for the generation of noxious bladder input and bladder overactivity in cystitis. J Urol 177: 1537-1541.

Chen J, Kim D, Bianchi BR, Cavanaugh EJ, Faltynek CR, Kym PR, Reilly RM. 2009. Pore dilation occurs in TRPA1 but not in TRPM8 channels. Mol Pain 5: 3.

Chen Y, Zhang Z, Lv XY, Wang YD, Hu ZG, Sun H, Tan RZ, Liu YH, Bian GH, Xiao Y, et al. 2008. Expression of Pkd212 in testis is implicated in spermatogenesis. Biol Pharm Bull 31: 1496-1500.

Cheng X, Jin J, Hu L, Shen D, Dong X-P, Samie MA, Knoff J, Eisinger B, Liu M-L, Huang SM, et al. 2010a. TRP Channel Regulates EGFR Signaling in Hair Morphogenesis and Skin Barrier Formation. Cell 141: 331-343.

Cheng X, Shen D, Samie M, Xu H. 2010b. Mucolipins: Intracellular TRPML1-3 channels. FEBS Lett 584: 2013-2021.

Chung MK, Guler AD, Caterina MJ. 2005. Biphasic currents evoked by chemical or thermal activation of the heat-gated ion channel, TRPV3. J Biol Chem 280: 15928-15941.

Chung MK, Guler AD, Caterina MJ. 2008. TRPV1 shows dynamic ionic selectivity during agonist stimulation. Nat Neurosci 11: 555-564.

Chung MK, Lee H, Caterina MJ. 2003. Warm temperatures activate TRPV4 in mouse 308 keratinocytes. J Biol Chem 278: 32037-32046.

Chung MK, Lee H, Mizuno A, Suzuki M, Caterina MJ. 2004. 2-aminoethoxydiphenyl borate activates and sensitizes the heat-gated ion channel TRPV3. J Neurosci 24: $5177-5182$.

Churchill GC, Okada Y, Thomas JM, Genazzani AA, Patel S, Galione A. 2002. NAADP mobilizes $\mathrm{Ca}(2+)$ from reserve granules, lysosome-related organelles, in sea urchin eggs. Cell 111: 703-708.
Clapham DE. 2003. TRP channels as cellular sensors. Nature 426: $517-524$.

Clapham DE, Nilius B, Owsianik G. 2009. Transient Receptor Potential Channels. Last modified on 2009-10-14. (IUPHAR-DB). http://www.iuphar-db. org/DATABASE/FamilyMenuForward?familyId=78.

Colsoul B, Schraenen A, Lemaire K, Quintens R, Van Lommel L, Segal A, Owsianik G, Talavera K, Voets T, Margolskee RF, et al. 2010. Loss of high-frequency glucose-induced $\mathrm{Ca}^{2+}$ oscillations in pancreatic islets correlates with impaired glucose tolerance in Trpm5-/mice. Proc Natl Acad Sci U S A 107: 5208-5213.

Corey DP, Garcia-Anoveros J, Holt JR, Kwan KY, Lin SY, Vollrath MA, Amalfitano A, Cheung EL, Derfler BH, Duggan A, et al. 2004. TRPA1 is a candidate for the mechanosensitive transduction channel of vertebrate hair cells. Nature 432: $723-730$.

Cuajungco MP, Samie MA. 2008. The varitint-waddler mouse phenotypes and the TRPML3 ion channel mutation: cause and consequence. Pflugers Arch 457: 463-473.

Curcio-Morelli C, Zhang P, Venugopal B, Charles FA, Browning MF, Cantiello HF, Slaugenhaupt SA. 2010. Functional multimerization of mucolipin channel proteins. J Cell Physiol 222: 328-335.

Damann N, Voets T, Nilius B. 2008. TRPs in Our Senses. Curr Biol 18: R880-R889.

De Ridder D, Baert L. 2000. Vanilloids and the overactive bladder. BJU Int 86: 172-180.

Delmas P. 2004. Polycystins: from mechanosensation to gene regulation. Cell 118: 145-148.

Delmas P, Padilla F, Osorio N, Coste B, Raoux M, Crest M. 2004. Polycystins, calcium signaling, and human diseases. Biochem Biophys Res Commun 322: 1374-1383.

den Dekker E, Hoenderop JG, Nilius B, Bindels RJ. 2003. The epithelial calcium channels, TRPV5 \& TRPV6: from identification towards regulation. Cell Calcium 33: 497-507.

Desai BN, Clapham DE. 2005. TRP channels and mice deficient in TRP channels. Pflugers Arch 451: 11-18.

Dhaka A, Viswanath V, Patapoutian A. 2006. Trp ion channels and temperature sensation. Annu Rev Neurosci 29: 135-161.

Di Palma F, Belyantseva IA, Kim HJ, Vogt TF, Kachar B, Noben-Trauth K. 2002. Mutations in Mcoln3 associated with deafness and pigmentation defects in varitintwaddler (Va) mice. Proc Natl Acad Sci U S A 99: 14994-14999.

Dietrich A, Chubanov V, Kalwa H, Rost BR, Gudermann T. 2006. Cation channels of the transient receptor potential superfamily: their role in physiological and pathophysiological processes of smooth muscle cells. Pharmacol Ther 112: $744-760$.

Dietrich A, Mederos YSM, Gollasch M, Gross V, Storch U, Dubrovska G, Obst M, Yildirim E, Salanova B, Kalwa $\mathrm{H}$, et al. 2005. Increased vascular smooth muscle contractility in TRPC6-/- mice. Mol Cell Biol 25: 6980-6989.

Dong XP, Cheng X, Mills E, Delling M, Wang F, Kurz T, Xu H. 2008. The type IV mucolipidosis-associated protein TRPML1 is an endolysosomal iron release channel. Nature 455: 992-996. 
Dong XP, Wang X, Shen D, Chen S, Liu M, Wang Y, Mills E, Cheng X, Delling M, Xu H. 2009. Activating mutations of the TRPML1 channel revealed by proline-scanning mutagenesis. J Biol Chem 284: 32040-32052.

Dong XP, Wang X, Xu H. 2010. TRP Channels of Intracellular Membranes. J Neurochem 113: 313-328.

Drews A, Loch S, Mohr F, Rizun O, Lambert S, Oberwinkler J. 2010. The fractional calcium current through fast ligand-gated TRPM channels. Acta Physiologica 198: 227.

Duncan LM, Deeds J, Cronin FE, Donovan M, Sober AJ, Kauffman M, McCarthy JJ. 2001. Melastatin expression and prognosis in cutaneous malignant melanoma. $J$ Clin Oncol 19: 568-576.

Duncan LM, Deeds J, Hunter J, Shao J, Holmgren LM, Woolf EA, Tepper RI, Shyjan AW. 1998. Down-regulation of the novel gene melastatin correlates with potential for melanoma metastasis. Cancer Res 58: 1515-1520.

Egan TM, Khakh BS. 2004. Contribution of calcium ions to P2X channel responses. J Neurosci 24: 3413-3420.

Elizondo MR, Arduini BL, Paulsen J, MacDonald EL, Sabel JL, Henion PD, Cornell RA, Parichy DM. 2005. Defective skeletogenesis with kidney stone formation in dwarf zebrafish mutant for trpm7. Curr Biol 15: 667-671.

Ellinor PT, Yang J, Sather WA, Zhang JF, Tsien RW. 1995. $\mathrm{Ca}^{2+}$ channel selectivity at a single locus for high-affinity $\mathrm{Ca}^{2+}$ interactions. Neuron 15: 1121-1132.

Everaerts W, Nilius B, Owsianik G. 2010. The vanilloid transient receptor potential channel Trpv4: From structure to disease. Prog Biophys Mol Biol 103: 2-17.

Everaerts W, Sepulveda MR, Gevaert T, Roskams T, Nilius B, De Ridder D. 2009. Where is TRPV1 expressed in the bladder, do we see the real channel? Naunyn Schmiedebergs Arch Pharmacol 379: 421-425.

Felder CC, Briley EM, Axelrod J, Simpson JT, Mackie K, Devane WA. 1993. Anandamide, an endogenous cannabimimetic eicosanoid, binds to the cloned human cannabinoid receptor and stimulates receptor-mediated signal transduction. Proc Natl Acad Sci U S A 90: 7656-7660.

Foggensteiner L, Bevan AP, Thomas R, Coleman N, Boulter C, Bradley J, Ibraghimov-Beskrovnaya $\mathrm{O}$, Klinger $\mathrm{K}$, Sandford R. 2000. Cellular and subcellular distribution of polycystin-2, the protein product of the $\mathrm{PKD} 2$ gene. J Am Soc Nephrol 11: 814-827.

Fonfria E, Murdock PR, Cusdin FS, Benham CD, Kelsell RE, McNulty S. 2006. Tissue distribution profiles of the human TRPM cation channel family. J Recept Signal Transduct Res 26: 159-178.

Freichel M, Suh SH, Pfeifer A, Schweig U, Trost C, Weissgerber P, Biel M, Philipp S, Freise D, Droogmans G, et al. 2001. Lack of an endothelial store-operated $\mathrm{Ca}^{2+}$ current impairs agonist-dependent vasorelaxation in TRP4-/- mice. Nat Cell Biol 3: 121-127.

Freichel M, Vennekens R, Olausson J, Stolz S, Philipp SE, Weissgerber P, Flockerzi V. 2005. Functional role of TRPC proteins in native systems: implications from knockout and knock-down studies. J Physiol 567: 59-66.

Gailly P, Colson-Van Schoor M. 2001. Involvement of trp-2 protein in store-operated influx of calcium in fibroblasts. Cell Calcium 30: 157-165.
Galione A, Churchill GC. 2002. Interactions between calcium release pathways: multiple messengers and multiple stores. Cell Calcium 32: 343-354.

Garcia-Martinez C, Morenilla-Palao C, Planells-Cases R, Merino JM, Ferrer-Montiel A. 2000. Identification of an aspartic residue in the P-loop of the vanilloid receptor that modulates pore properties. J Biol Chem 275: 32552-32558.

Gaudet R. 2008a. A primer on ankyrin repeat function in TRP channels and beyond. Mol Biosyst 4: 372-379.

Gaudet R. 2008b. TRP channels entering the structural era. J Physiol 586: 3565-3575.

Gaudet R. 2009. Divide and Conquer: High Resolution Structural Information on TRP Channel Fragments. J Gen Physiol 133: 231-237.

Geng L, Segal Y, Pavlova A, Barros EJ, Lohning C, Lu W, Nigam SK, Frischauf AM, Reeders ST, Zhou J. 1997. Distribution and developmentally regulated expression of murine polycystin. Am J Physiol 272: F451-F459.

Gibson HE, Edwards JG, Page RS, Van Hook MJ, Kauer JA. 2008. TRPV1 channels mediate long-term depression at synapses on hippocampal interneurons. Neuron 57: 746-759.

Goel M, Sinkins WG, Schilling WP. 2002. Selective association of TRPC channel subunits in rat brain synaptosomes. J Biol Chem 277: 48303-48310.

Gokce O, Runne H, Kuhn A, Luthi-Carter R. 2009. Shortterm striatal gene expression responses to brain-derived neurotrophic factor are dependent on MEK and ERK activation. PLoS ONE 4: e5292.

Gopinath P, Wan E, Holdcroft A, Facer P, Davis JB, Smith GD, Bountra C, Anand P. 2005. Increased capsaicin receptor TRPV1 in skin nerve fibres and related vanilloid receptors TRPV3 and TRPV4 in keratinocytes in human breast pain. BMC Womens Health 5: 2 .

Gordon-Shaag A, Zagotta WN, Gordon SE. 2008. Mechanism of $\mathrm{Ca}^{2+}$-dependent desensitization of TRP channels. Channels 2: 125-129.

Gottlieb P, Folgering J, Maroto R, Raso A, Wood TG, Kurosky A, Bowman C, Bichet D, Patel A, Sachs F, et al. 2008. Revisiting TRPC1 and TRPC6 mechanosensitivity. Pflugers Arch 455: 1097-1103.

Graham S, Ding M, Sours-Brothers S, Yorio T, Ma JX, Ma R. 2007. Downregulation of TRPC6 protein expression by high glucose, a possible mechanism for the impaired $\mathrm{Ca}^{2+}$ signaling in glomerular mesangial cells in diabetes. Am J Physiol Renal Physiol 293: F1381-F1390.

Greka A, Navarro B, Oancea E, Duggan A, Clapham DE. 2003. TRPC5 is a regulator of hippocampal neurite length and growth cone morphology. Nat Neurosci 6: 837-845.

Grimm C, Jors S, Saldanha SA, Obukhov AG, Pan B, Oshima K, Cuajungco MP, Chase P, Hodder P, Heller S. 2010. Small Molecule Activators of TRPML3. Chem Biol 17: $135-148$.

Grimm C, Kraft R, Sauerbruch S, Schultz G, Harteneck C. 2003. Molecular and functional characterization of the melastatin-related cation channel TRPM3.J Biol Chem 278: $21493-21501$.

Grimm C, Kraft R, Schultz G, Harteneck C. 2005. Activation of the melastatin-related cation channel TRPM3 by 
D-erythro-sphingosine [corrected]. Mol Pharmacol 67: 798-805.

Guo L, Schreiber TH, Weremowicz S, Morton CC, Lee C, Zhou J. 2000. Identification and characterization of a novel polycystin family member, polycystin-L2, in mouse and human: sequence, expression, alternative splicing, and chromosomal localization. Genomics 64: 241-251.

Hagenacker T, Czeschik JC, Schafers M, Busselberg D. 2010. Sensitization of voltage activated calcium channel currents for capsaicin in nociceptive neurons by tumornecrosis-factor-alpha. Brain Res Bull 81: 157-163.

Hanaoka K, Qian F, Boletta A, Bhunia AK, Piontek K, Tsiokas L, Sukhatme VP, Guggino WB, Germino GG. 2000. Co-assembly of polycystin-1 and -2 produces unique cation-permeable currents. Nature 408: 990-994.

Hassock SR, Zhu MX, Trost C, Flockerzi V, Authi KS. 2002. Expression and role of TRPC proteins in human platelets: evidence that TRPC6 forms the store-independent calcium entry channel. Blood 100: 2801-2811.

Hayes P, Meadows HJ, Gunthorpe MJ, Harries MH, Duckworth DM, Cairns W, Harrison DC, Clarke CE, Ellington K, Prinjha RK, et al. 2000. Cloning and functional expression of a human orthologue of rat vanilloid receptor-1. Pain 88: 205-215.

Hoenderop JG, Nilius B, Bindels RJ. 2005. Calcium absorption across epithelia. Physiol Rev 85: 373-422.

Hoenderop JG, Voets T, Hoefs S, Weidema F, Prenen J, Nilius B, Bindels RJ. 2003. Homo- and heterotetrameric architecture of the epithelial $\mathrm{Ca}^{2+}$ channels TRPV5 and TRPV6. Embo J 22: 776-785.

Hofmann T, Schaefer M, Schultz G, Gudermann T. 2000. Transient receptor potential channels as molecular substrates of receptor-mediated cation entry. J Mol Med 78: $14-25$.

Hofmann T, Schaefer M, Schultz G, Gudermann T. 2002. Subunit composition of mammalian transient receptor potential channels in living cells. Proc Natl Acad Sci U S A 99: 7461-7466.

Huang AL, Chen X, Hoon MA, Chandrashekar J, Guo W, Trankner D, Ryba NJ, Zuker CS. 2006. The cells and logic for mammalian sour taste detection. Nature 442: 934-938.

Huang WC, Young JS, Glitsch MD. 2007. Changes in TRPC channel expression during postnatal development of cerebellar neurons. Cell Calcium 42: 1-10.

Hughes J, Ward CJ, Peral B, Aspinwall R, Clark K, San Millan JL, Gamble V, Harris PC. 1995. The polycystic kidney disease 1 (PKD1) gene encodes a novel protein with multiple cell recognition domains. Nat Genet 10: 151-160.

Inoue R, Okada T, Onoue H, Hara Y, Shimizu S, Naitoh S, Ito Y, Mori Y. 2001. The transient receptor potential protein homologue TRP6 is the essential component of vascular alpha(1)-adrenoceptor-activated $\mathrm{Ca}(2+)$-permeable cation channel. Circ Res 88: 325-332.

Ishimaru $\mathrm{Y}$, Inada $\mathrm{H}$, Kubota $\mathrm{M}$, Zhuang $\mathrm{H}$, Tominaga $\mathrm{M}$, Matsunami H. 2006. Transient receptor potential family members PKD1L3 and PKD2L1 form a candidate sour taste receptor. Proc Natl Acad Sci U S A 103: 12569-12574.

Iwata Y, Katanosaka Y, Arai Y, Komamura K, Miyatake K, Shigekawa M. 2003. A novel mechanism of myocyte degeneration involving the $\mathrm{Ca}^{2+}$-permeable growth factor-regulated channel. J Cell Biol 161: 957-967.

Iwata Y, Katanosaka Y, Arai Y, Shigekawa M, Wakabayashi S. 2009. Dominant-negative inhibition of $\mathrm{Ca}^{2+}$ influx via TRPV2 ameliorates muscular dystrophy in animal models. Hum Mol Genet 18: 824-834.

Ju YK, Allen DG. 2007. Store-operated $\mathrm{Ca}^{2+}$ entry and TRPC expression; possible roles in cardiac pacemaker tissue. Heart Lung Circ 16: 349-355.

Jung S, Muhle A, Schaefer M, Strotmann R, Schultz G, Plant TD. 2003. Lanthanides potentiate TRPC 5 currents by an action at extracellular sites close to the pore mouth. J Biol Chem 278: 3562-3571.

Jung S, Strotmann R, Schultz G, Plant TD. 2002. TRPC6 is a candidate channel involved in receptor-stimulated cation currents in A7r5 smooth muscle cells. Am J Physiol Cell Physiol 282: C347-C359.

Kamouchi M, Philipp S, Flockerzi V, Wissenbach U, Mamin A, Raeymaekers L, Eggermont J, Droogmans G, Nilius B. 1999. Properties of heterologously expressed hTRP3 channels in bovine pulmonary artery endothelial cells. J Physiol (Lond) 518: 345-358.

Kanzaki M, Zhang YQ, Mashima H, Li L, Shibata H, Kojima I. 1999. Translocation of a calcium-permeable cation channel induced by insulin-like growth factor-I. Nat Cell Biol 1: 165-170.

Karacsonyi C, Miguel AS, Puertollano R. 2007. Mucolipin-2 localizes to the Arf6-associated pathway and regulates recycling of GPI-APs. Traffic 8: 1404-1414.

Karashima Y, Damann N, Prenen J, Talavera K, Segal A, Voets T, Nilius B. 2007. Bimodal action of menthol on the transient receptor potential channel TRPA1. J Neurosci 27: 9874-9884.

Karashima Y, Prenen J, Talavera K, Janssens A, Voets T, Nilius B. 2010. Agonist-Induced Changes in $\mathrm{Ca}(2+)$ Permeation through the Nociceptor Cation Channel TRPA1. Biophys J 98: 773-783.

Karashima Y, Talavera K, Everaerts W, Janssens A, Kwan KY, Vennekens R, Nilius B, Voets T. 2009. TRPA1 acts as a cold sensor in vitro and in vivo. Proc Natl Acad Sci U S A 106: 1273-1278.

Keller SA, Jones JM, Boyle A, Barrow LL, Killen PD, Green DG, Kapousta NV, Hitchcock PF, Swank RT, Meisler MH. 1994. Kidney and retinal defects (Krd), a transgene-induced mutation with a deletion of mouse chromosome 19 that includes the Pax2 locus. Genomics 23: $309-320$.

Kim BJ, So I, Kim KW. 2006. The relationship of TRP channels to the pacemaker activity of interstitial cells of Cajal in the gastrointestinal tract. J Smooth Muscle Res 42: 1-7.

Kim EY, Alvarez-Baron CP, Dryer SE. 2009a. TRPC3 and TRPC6 associate with $\mathrm{BK}_{\mathrm{Ca}}$ channels: Role in $\mathrm{BK}_{\mathrm{Ca}}$ trafficking to the surface of cultured podocytes. Mol Pharmacol 75: 466-477.

Kim HJ, Li Q, Tjon-Kon-Sang S, So I, Kiselyov K, Muallem S. 2007. Gain-of-function mutation in TRPML3 causes the mouse Varitint-Waddler phenotype. J Biol Chem 282: 36138-36142.

Kim HJ, Li Q, Tjon-Kon-Sang S, So I, Kiselyov K, Soyombo AA, Muallem S. 2008. A novel mode of TRPML3 
regulation by extracytosolic $\mathrm{pH}$ absent in the varitintwaddler phenotype. Embo J 27: 1197-1205.

Kim HJ, Soyombo AA, Tjon-Kon-Sang S, So I, Muallem S 2009b. The $\mathrm{Ca}(2+)$ channel TRPML3 regulates membrane trafficking and autophagy. Traffic 10: 1157-1167.

Kim MS, Zeng W, Yuan JP, Shin DM, Worley PF, Muallem S. 2009c. Native Store-operated $\mathrm{Ca}^{2+}$ Influx Requires the Channel Function of Orail and TRPC1. J Biol Chem 284: $9733-9741$.

Kim SJ, Kim YS, Yuan JP, Petralia RS, Worley PF, Linden DJ. 2003. Activation of the TRPC1 cation channel by metabotropic glutamate receptor mGluR1. Nature 426: 285-291.

Kiselyov K, Patterson RL. 2009. The integrative function of TRPC channels. Front Biosci 14: 45-58.

Koike C, Obara T, Uriu Y, Numata T, Sanuki R, Miyata K, Koyasu T, Ueno S, Funabiki K, Tani A, et al. 2010. TRPM1 is a component of the retinal ON bipolar cell transduction channel in the mGluR6 cascade. Proc Natl Acad Sci U S A 107: 332-337.

Kokrashvili Z, Rodriguez D, Yevshayeva V, Zhou H, Margolskee RF, Mosinger B. 2009. Release of endogenous opioids from duodenal enteroendocrine cells requires Trpm5. Gastroenterology 137: 598-606, 606 e1-2.

Koulen P, Cai Y, Geng L, Maeda Y, Nishimura S, Witzgall R, Ehrlich BE, Somlo S. 2002. Polycystin-2 is an intracellular calcium release channel. Nat Cell Biol 4: 191-197.

Kraft R, Harteneck C. 2005. The mammalian melastatinrelated transient receptor potential cation channels: an overview. Pflugers Arch 451: 204-211.

Krapivinsky G, Mochida S, Krapivinsky L, Cibulsky SM, Clapham DE. 2006. The TRPM7 Ion Channel Functions in Cholinergic Synaptic Vesicles and Affects Transmitter Release. Neuron 52: 485-496.

Kuhn FJ, Heiner I, Luckhoff A. 2005. TRPM2: a calcium influx pathway regulated by oxidative stress and the novel second messenger ADP-ribose. Pflugers Arch 451: 212-219.

Kwan HY, Huang Y, Yao X. 2007. TRP channels in endothelial function and dysfunction. Biochim Biophys Acta 1772: 907-914.

Kwan HY, Shen B, Ma X, Kwok YC, Huang Y, Man YB, Yu S, Yao X. 2009. TRPC1 Associates With $\mathrm{BK}_{\mathrm{Ca}}$ Channel to Form a Signal Complex in Vascular Smooth Muscle Cells. Circ Res 104: 670-U207.

Kwan KY, Allchorne AJ, Vollrath MA, Christensen AP, Zhang DS, Woolf CJ, Corey DP. 2006. TRPA1 contributes to cold, mechanical, and chemical nociception but is not essential for hair-cell transduction. Neuron 50: 277-289.

Lange I, Yamamoto S, Partida-Sanchez S, Mori Y, Fleig A, Penner R. 2009. TRPM2 functions as a lysosomal $\mathrm{Ca}^{2+}$ release channel in beta cells. Sci Signal 2: ra23.

LaPlante JM, Falardeau J, Sun M, Kanazirska M, Brown EM, Slaugenhaupt SA, Vassilev PM. 2002. Identification and characterization of the single channel function of human mucolipin-1 implicated in mucolipidosis type IV, a disorder affecting the lysosomal pathway. FEBS Lett 532: 183-187.

Larsson KP, Peltonen HM, Bart G, Louhivuori LM, Penttonen A, Antikainen M, Kukkonen JP, Akerman KE. 2005. Orexin-A-induced $\mathrm{Ca}^{2+}$ entry: evidence for involvement of trpc channels and protein kinase $\mathrm{C}$ regulation. J Biol Chem 280: 1771-1781.

Latorre R, Zaelzer C, Brauchi S. 2009. Structure-functional intimacies of transient receptor potential channels. Q Rev Biophys 42: 201-246.

Lee KP, Jun JY, Chang IY, Suh SH, So I, Kim KW. 2005. TRPC4 is an essential component of the nonselective cation channel activated by muscarinic stimulation in mouse visceral smooth muscle cells. Mol Cells 20: $435-441$.

Lee N, Chen J, Sun L, Wu S, Gray KR, Rich A, Huang M, Lin JH, Feder JN, Janovitz EB, et al. 2003. Expression and characterization of human transient receptor potential melastatin 3 (hTRPM3). J Biol Chem 278: 20890-20897.

Lemonnier L, Trebak M, Putney JW Jr. 2008. Complex regulation of the TRPC3, 6 and 7 channel subfamily by diacylglycerol and phosphatidylinositol-4,5-bisphosphate. Cell Calcium 43: 506-514.

Li HB, Mao RR, Zhang JC, Yang Y, Cao J, Xu L. 2008. Antistress Effect of TRPV1 Channel on Synaptic Plasticity and Spatial Memory. Biol Psychiatry 64: 286-292.

Li M, Du J, Jiang J, Ratzan W, Su LT, Runnels LW, Yue L. 2007. Molecular determinants of $\mathrm{Mg}^{2+}$ and $\mathrm{Ca}^{2+}$ permeability and $\mathrm{pH}$ sensitivity in TRPM6 and TRPM7. J Biol Chem 282: 25817-25830.

Li X, Luo Y, Starremans PG, McNamara CA, Pei Y, Zhou J. 2005. Polycystin-1 and polycystin-2 regulate the cell cycle through the helix-loop-helix inhibitor Id2. Nat Cell Biol 7: $1102-1112$.

Li Y, Calfa G, Inoue T, Amaral MD, Pozzo-Miller L. 2010. Activity-Dependent release of endogenous BDNF from mossy fibers evokes a TRPC 3 current and $\mathrm{Ca}^{2+}$ elevations in Ca3 pyramidal neurons. J Neurophysiol 103: $2846-$ 2856.

Li Z, Sergouniotis PI, Michaelides M, Mackay DS, Wright GA, Devery S, Moore AT, Holder GE, Robson AG, Webster AR. 2009. Recessive mutations of the gene TRPM1 abrogate ON bipolar cell function and cause complete congenital stationary night blindness in humans. Am J Hum Genet 85: 711-719.

Liao Y, Erxleben C, Yildirim E, Abramowitz J, Armstrong DL, Birnbaumer L. 2007. Orai proteins interact with TRPC channels and confer responsiveness to store depletion. Proc Natl Acad Sci U S A 104: 4682-4687.

Liedtke W, Friedman JM. 2003. Abnormal osmotic regulation in trpv4-/- mice. Proc Natl Acad Sci U S A 100: 13698-13703.

Link TM, Park U, Vonakis BM, Raben DM, Soloski MJ, Caterina MJ. 2010. TRPV2 has a pivotal role in macrophage particle binding and phagocytosis. Nat Immunol 11: 232-239.

Liu CH, Wang T, Postma M, Obukhov AG, Montell C, Hardie RC. 2007a. In vivo identification and manipulation of the $\mathrm{Ca}^{2+}$ selectivity filter in the Drosophila transient receptor potential channel. J Neurosci 27: 604-615.

Liu X, Cheng KT, Bandyopadhyay BC, Pani B, Dietrich A, Paria BC, Swaim WD, Beech D, Yildrim E, Singh BB, et al. 2007b. Attenuation of store-operated $\mathrm{Ca}^{2+}$ current impairs salivary gland fluid secretion in TRPC1(-/-) mice. Proc Natl Acad Sci U S A 104: 17542-17547. 
Liu X, Singh BB, Ambudkar IS. 2003. TRPC1 is required for functional store-operated $\mathrm{Ca}^{2+}$ channels. Role of acidic amino acid residues in the S5-S6 region. J Biol Chem 278: 11337-11343.

Lu M, Branstrom R, Berglund E, Hoog A, Bjorklund P, Westin G, Larsson C, Farnebo LO, Forsberg L. 2010. Expression and association of TRPC subtypes with Orail and STIM1 in human parathyroid. J Mol Endocrinol 44: 285-294.

Luo Y, Vassilev PM, Li X, Kawanabe Y, Zhou J. 2003. Native polycystin 2 functions as a plasma membrane $\mathrm{Ca}^{2+}$. permeable cation channel in renal epithelia. Mol Cell Biol 23: 2600-2607.

Luzio JP, Bright NA, Pryor PR. 2007a. The role of calcium and other ions in sorting and delivery in the late endocytic pathway. Biochem Soc Trans 35: 1088-1091.

Luzio JP, Pryor PR, Bright NA. 2007b. Lysosomes: fusion and function. Nat Rev Mol Cell Biol 8: 622-632.

Macpherson LJ, Dubin AE, Evans MJ, Marr F, Schultz PG, Cravatt BF, Patapoutian A. 2007. Noxious compounds activate TRPA1 ion channels through covalent modification of cysteines. Nature 445: 541-545.

Macpherson LJ, Geierstanger BH, Viswanath V, Bandell M, Eid SR, Hwang S, Patapoutian A. 2005. The pungency of garlic: activation of TRPA1 and TRPV1 in response to allicin. Curr Biol 15: 929-934.

Mahieu F, Owsianik G, Verbert L, Janssens A, De Smedt H, Nilius B, Voets T. 2007. TRPM8-independent mentholinduced $\mathrm{Ca}^{2+}$ release from endoplasmic reticulum and Golgi. J Biol Chem 282: 3325-3336.

Mandadi S, Sokabe T, Shibasaki K, Katanosaka K, Mizuno A, Moqrich A, Patapoutian A, Fukumi-Tominaga T, Mizumura K, Tominaga M. 2009. TRPV3 in keratinocytes transmits temperature information to sensory neurons via ATP. Pflugers Arch 458: 1093-1102.

Maroto R, Raso A, Wood TG, Kurosky A, Martinac B, Hamill OP. 2005. TRPC1 forms the stretch-activated cation channel in vertebrate cells. Nat Cell Biol 7: 179-185.

Martina JA, Lelouvier B, Puertollano R. 2009. The calcium channel mucolipin-3 is a novel regulator of trafficking along the endosomal pathway. Traffic 10: 1143-1156.

Masuyama R, Vriens J, Voets T, Karashima Y, Owsianik G, Vennekens R, Lieben L, Torrekens S, Moermans K, Vanden Bosch A, et al. 2008. TRPV4-mediated calcium influx regulates terminal differentiation of osteoclasts. Cell Metab 8: 257-265.

Matsuura H, Sokabe T, Kohno K, Tominaga M, Kadowaki T. 2009. Evolutionary conservation and changes in insect TRP channels. BMC Evol Biol 9: 228.

McKemy DD, Neuhausser WM, Julius D. 2002. Identification of a cold receptor reveals a general role for TRP channels in thermosensation. Nature 416: 52-58.

McNeill MS, Paulsen J, Bonde G, Burnight E, Hsu MY, Cornell RA. 2007. Cell death of melanophores in zebrafish trpm7 mutant embryos depends on melanin synthesis. J Invest Dermatol 127: 2020-2030.

McNulty S, Fonfria E. 2005. The role of TRPM channels in cell death. Pflugers Arch 451: 235-242.

Mederos y Schnitzler M, Waring J, Gudermann T, Chubanov V. 2008. Evolutionary determinants of divergent calcium selectivity of TRPM channels. Faseb J 22: 1540-1551.
Miller AJ, Du J, Rowan S, Hershey CL, Widlund HR, Fisher DE. 2004. Transcriptional regulation of the melanoma prognostic marker melastatin (TRPM1) by MITF in melanocytes and melanoma. Cancer Res 64: 509-516.

Mizoguchi F, Mizuno A, Hayata T, Nakashima K, Heller S, Ushida T, Sokabe M, Miyasaka N, Suzuki M, Ezura Y, et al. 2008. Transient receptor potential vanilloid 4 deficiency suppresses unloading-induced bone loss. J Cell Physiol 216: 47-53.

Monteilh-Zoller MK, Hermosura MC, Nadler MJ, Scharenberg AM, Penner R, Fleig A. 2003. TRPM7 provides an ion channel mechanism for cellular entry of trace metal ions. J Gen Physiol 121: 49-60.

Montell C. 2003. The venerable inveterate invertebrate TRP channels. Cell Calcium 33: 409-417.

Montell C. 2005. The TRP superfamily of cation channels. Sci STKE 2005: re3.

Montell C, Birnbaumer L, Flockerzi V. 2002. The TRP channels, a remarkably functional family. Cell 108: 595-598.

Montell C, Rubin GM. 1989. Molecular characterization of the Drosophila trp locus: a putative integral membrane protein required for phototransduction. Neuron 2: 1313-1323.

Moqrich A, Hwang SW, Earley TJ, Petrus MJ, Murray AN, Spencer KS, Andahazy M, Story GM, Patapoutian A. 2005. Impaired thermosensation in mice lacking TRPV3, a heat and camphor sensor in the skin. Science 307: 1468-1472.

Mori Y, Wakamori M, Miyakawa T, Hermosura M, Hara Y, Nishida M, Hirose K, Mizushima A, Kurosaki M, Mori E, et al. 2002. Transient receptor potential 1 regulates capacitative $\mathrm{Ca}(2+)$ entry and $\mathrm{Ca}(2+)$ release from endoplasmic reticulum in B lymphocytes. $J$ Exp Med 195: 673-681.

Muraki K, Iwata Y, Katanosaka Y, Ito T, Ohya S, Shigekawa M, Imaizumi Y. 2003. TRPV2 is a component of osmotically sensitive cation channels in murine aortic myocytes. Circ Res 93: 829-838.

Muramatsu S, Wakabayashi M, Ohno T, Amano K, Ooishi R, Sugahara T, Shiojiri S, Tashiro K, Suzuki Y, Nishimura R, et al. 2007. Functional gene screening system identified TRPV4 as a regulator of chondrogenic differentiation. J Biol Chem 282: 32158-32167.

Nagata K, Zheng L, Madathany T, Castiglioni AJ, Bartles JR, Garcia-Anoveros J. 2008. The varitint-waddler (Va) deafness mutation in TRPML3 generates constitutive, inward rectifying currents and causes cell degeneration. Proc Natl Acad Sci U S A 105: 353-358.

Nathan JD, Patel AA, McVey DC, Thomas JE, Prpic V, Vigna SR, Liddle RA. 2001. Capsaicin vanilloid receptor-1 mediates substance $P$ release in experimental pancreatitis. Am J Physiol Gastrointest Liver Physiol 281: G1322-1328.

Newby LJ, Streets AJ, Zhao Y, Harris PC, Ward CJ, Ong AC. 2002. Identification, characterization, and localization of a novel kidney polycystin-1-polycystin-2 complex. J Biol Chem 277: 20763-20773.

Ng LC, McCormack MD, Airey JA, Singer CA, Keller PS, Shen XM, Hume JR. 2009. TRPC1 and STIM1 mediate capacitative $\mathrm{Ca}^{2+}$ entry in mouse pulmonary arterial smooth muscle cells. J Physiol 587: 2429-2442. 
Nijenhuis T, Hoenderop JG, Nilius B, Bindels RJ. 2003a. (Patho)physiological implications of the novel epithelial $\mathrm{Ca}^{2+}$ channels TRPV5 and TRPV6. Pflugers Arch 446: 401-409.

Nijenhuis T, Hoenderop JG, van der Kemp AW, Bindels RJ. 2003b. Localization and regulation of the epithelial $\mathrm{Ca}^{2+}$ channel TRPV6 in the kidney. J Am Soc Nephrol 14: $2731-2740$.

Nilius B, Droogmans G. 2001. Ion channels and their functional role in vascular endothelium. Physiol Rev 81: $1415-1459$.

Nilius B, Mahieu F, Prenen J, Janssens A, Owsianik G, Vennekens R, Voets T. 2006. The $\mathrm{Ca}^{2+}$-activated cation channel TRPM4 is regulated by phosphatidylinositol 4,5-biphosphate. EMBO Journal 25: 467-478.

Nilius B, Owsianik G, Voets T. 2008. Transient receptor potential channels meet phosphoinositides. Embo J 27: 2809-2816.

Nilius B, Owsianik G, Voets T, Peters JA. 2007. Transient Receptor Potential Channels in Disease. Physiol Rev 87: $165-217$.

Nilius B, Prenen J, Hoenderop JG, Vennekens R, Hoefs S, Weidema AF, Droogmans G, Bindels RJ. 2002. Fast and slow inactivation kinetics of the $\mathrm{Ca}^{2+}$ channels $\mathrm{ECaC} 1$ and ECaC2 (TRPV5 and TRPV6). Role of the intracellular loop located between transmembrane segments 2 and 3. J Biol Chem 277: 30852-30858.

Nilius B, Prenen J, Janssens A, Owsianik G, Wang C, Zhu MX, Voets T. 2005a. The selectivity filter of the cation channel TRPM4. J Biol Chem 280: 22899-22906.

Nilius B, Prenen J, Tang J, Wang C, Owsianik G, Janssens A, Voets T, Zhu MX. 2005b. Regulation of the $\mathrm{Ca}^{2+}$ Sensitivity of the Nonselective Cation Channel TRPM4. J Biol Chem 280: 6423-6433.

Nilius B, Vennekens R. 2006. From cardiac cation channels to the molecular dissection of the transient receptor potential channel TRPM4. Pflugers Arch Europ J Physiol 453: 313-321.

Nilius B, Vennekens R, Prenen J, Hoenderop JG, Bindels RJ, Droogmans G. 2000. Whole-cell and single channel monovalent cation currents through the novel rabbit epithelial $\mathrm{Ca}^{2+}$ channel ECaC. J Physiol 527: 239-248.

Nilius B, Vennekens R, Prenen J, Hoenderop JG, Droogmans G, Bindels RJ. 2001. The single pore residue Asp542 determines $\mathrm{Ca}^{2+}$ permeation and $\mathrm{Mg}^{2+}$ block of the epithelial $\mathrm{Ca}^{2+}$ channel. J Biol Chem 276: 1020-1025.

Nilius B, Vriens J, Prenen J, Droogmans G, Voets T. 2004. TRPV4 calcium entry channel: a paradigm for gating diversity. Am J Physiol Cell Physiol 286: C195-C205.

Nilius B, Watanabe H, Vriens J. 2003. The TRPV4 channel: structure-function relationship and promiscuous gating behaviour. Pflugers Arch 446: 298-303.

Nomura H, Turco AE, Pei Y, Kalaydjieva L, Schiavello T, Weremowicz S, Ji W, Morton CC, Meisler M, Reeders ST, et al. 1998. Identification of PKDL, a novel polycystic kidney disease 2-like gene whose murine homologue is deleted in mice with kidney and retinal defects. J Biol Chem 273: 25967-25973.

Oancea E, Vriens J, Brauchi S, Jun J, Splawski I, Clapham DE. 2009. TRPM1 forms ion channels associated with melanin content in melanocytes. Sci Signal 2: ra21.
Obukhov AG, Nowycky MC. 2004. TRPC5 activation kinetics are modulated by the scaffolding protein ezrin/ radixin/moesin-binding phosphoprotein-50 (EBP50). J Cell Physiol 201: 227-235.

Obukhov AG, Nowycky MC. 2008. TRPC5 channels undergo changes in gating properties during the activation-deactivation cycle. J Cell Physiol 216: 162-171.

Olah Z, Szabo T, Karai L, Hough C, Fields RD, Caudle RM, Blumberg PM, Iadarola MJ. 2001. Ligand-induced dynamic membrane changes and cell deletion conferred by vanilloid receptor 1. J Biol Chem 276: 11021-11030.

Owsianik G, D’Hoedt D, Voets T, Nilius B. 2006a. Structurefunction relationship of the TRP channel superfamily. Rev Physiol Biochem Pharmacol 156: 61-90.

Owsianik G, Talavera K, Voets T, Nilius B. 2006b. Permeation and selectivity of trp channels. Annu Rev Physiol 68: $685-717$.

Pani B, Ong HL, Liu X, Rauser K, Ambudkar IS, Singh BB. 2008. Lipid rafts determine clustering of STIM1 in endoplasmic reticulum-plasma membrane junctions and regulation of store-operated $\mathrm{Ca}^{2+}$ entry (SOCE). J Biol Chem 283: 17333-17340.

Patapoutian A, Peier AM, Story GM, Viswanath V. 2003. ThermoTRP channels and beyond: mechanisms of temperature sensation. Nat Rev Neurosci 4: 529-539.

Patel S, Marchant JS, Brailoiu E. 2010. Two-pore channels: Regulation by NAADP and customized roles in triggering calcium signals. Cell Calcium 47: 480-490.

Pedersen SF, Owsianik G, Nilius B. 2005. TRP channels: an overview. Cell Calcium 38: 233-252.

Peier AM, Moqrich A, Hergarden AC, Reeve AJ, Andersson DA, Story GM, Earley TJ, Dragoni I, McIntyre P, Bevan S, et al. 2002a. A TRP channel that senses cold stimuli and menthol. Cell 108: 705-715.

Peier AM, Reeve AJ, Andersson DA, Moqrich A, Earley TJ, Hergarden AC, Story GM, Colley S, Hogenesch JB, McIntyre P, et al. 2002b. A heat-sensitive TRP channel expressed in keratinocytes. Science 296: 2046-2049.

Peng L, Popescu DC, Wang N, Shieh BH. 2007. Anchoring TRP to the INAD macromolecular complex requires the last 14 residues in its carboxyl terminus. J Neurochem 104: $1526-1535$.

Pennekamp P, Karcher C, Fischer A, Schweickert A, Skryabin B, Horst J, Blum M, Dworniczak B. 2002. The ion channel polycystin-2 is required for left-right axis determination in mice. Curr Biol 12: 938-943.

Perraud AL, Fleig A, Dunn CA, Bagley LA, Launay P, Schmitz C, Stokes AJ, Zhu Q, Bessman MJ, Penner R, et al. 2001. ADP-ribose gating of the calcium-permeable LTRPC2 channel revealed by Nudix motif homology. Nature 411: 595-599.

Perraud AL, Schmitz C, Scharenberg AM. 2003. TRPM2 $\mathrm{Ca}^{2+}$ permeable cation channels: from gene to biological function. Cell Calcium 33: 519-531.

Peters JH, McDougall SJ, Fawley JA, Smith SM, Andresen MC. 2010. Primary Afferent Activation of Thermosensitive TRPV1 Triggers Asynchronous Glutamate Release at Central Neurons. Neuron 65: 657-669.

Philipp S, Strauss B, Hirnet D, Wissenbach U, Mery L, Flockerzi V, Hoth M. 2003. TRPC3 mediates T-cell 
receptor-dependent calcium entry in human T-lymphocytes. J Biol Chem 278: 26629-26638.

Philipp S, Trost C, Warnat J, Rautmann J, Himmerkus N, Schroth G, Kretz O, Nastainczyk W, Cavalie A, Hoth M, et al. 2000. TRP4 (CCE1) protein is part of native calcium release-activated $\mathrm{Ca}^{2+}$-like channels in adrenal cells. J Biol Chem 275: 23965-23972.

Prasad P, Yanagihara AA, Small-Howard AL, Turner H, Stokes AJ. 2008. Secretogranin III directs secretory vesicle biogenesis in mast cells in a manner dependent upon interaction with chromogranin A. J Immunol 181: 5024-5034.

Pryor PR, Mullock BM, Bright NA, Gray SR, Luzio JP. 2000. The role of intraorganellar $\mathrm{Ca}(2+)$ in late endosomelysosome heterotypic fusion and in the reformation of lysosomes from hybrid organelles. J Cell Biol 149: 1053-1062.

Puertollano R, Kiselyov K. 2009. TRPMLs: in sickness and in health. Am J Physiol Renal Physiol 296: F1245-F1254.

Ramsey IS, Delling M, Clapham DE. 2006. An introduction to TRP channels. Annu Rev Physiol 68: 619-647.

Raychowdhury MK, Gonzalez-Perrett S, Montalbetti N, Timpanaro GA, Chasan B, Goldmann WH, Stahl S, Cooney A, Goldin E, Cantiello HF. 2004. Molecular pathophysiology of mucolipidosis type IV: $\mathrm{pH}$ dysregulation of the mucolipin-1 cation channel. Hum Mol Genet 13: 617-627.

Redondo PC, Jardin I, Lopez JJ, Salido GM, Rosado JA. 2008. Intracellular $\mathrm{Ca}(2+)$ store depletion induces the formation of macromolecular complexes involving hTRPC1, hTRPC6, the type II IP(3) receptor and SERCA3 in human platelets. Biochim Biophys Acta 1783: 1163-1176.

Reiser J, Polu KR, Moller CC, Kenlan P, Altintas MM, Wei C, Faul C, Herbert S, Villegas I, Avila-Casado C, et al. 2005. TRPC6 is a glomerular slit diaphragm-associated channel required for normal renal function. Nat Genet 37: 739-744.

Riccio A, Li Y, Moon J, Kim KS, Smith KS, Rudolph U, Gapon S, Yao GL, Tsvetkov E, Rodig SJ, et al. 2009. Essential role for TRPC5 in amygdala function and fear-related behavior. Cell 137: 761-772.

Riccio A, Mattei C, Kelsell RE, Medhurst AD, Calver AR, Randall AD, Davis JB, Benham CD, Pangalos MN. 2002a. Cloning and functional expression of human short TRP7, a candidate protein for store-operated $\mathrm{Ca}^{2+}$ influx. J Biol Chem 277: 12302-12309.

Riccio A, Medhurst AD, Mattei C, Kelsell RE, Calver AR, Randall AD, Benham CD, Pangalos MN. 2002b. mRNA distribution analysis of human TRPC family in CNS and peripheral tissues. Brain Res Mol Brain Res 109: 95-104.

Rohacs T. 2007. Regulation of TRP channels by PIP2. Pflugers Arch Europ J Physiol 453: 753-762.

Rohacs T. 2009. Phosphoinositide regulation of noncanonical transient receptor potential channels. Cell Calcium 45: 554-565.

Rohacs T, Nilius B. 2007. Regulation of transient receptor potential (trp) channels by phosphoinositides. Pflugers Arch 455: 157-168.
Rundle DR, Gorbsky G, Tsiokas L. 2004. PKD2 interacts and co-localizes with mDial to mitotic spindles of dividing cells: role of mDia1 IN PKD2 localization to mitotic spindles. J Biol Chem 279: 29728-29739.

Runnels LW, Yue L, Clapham DE. 2001. TRP-PLIK, a bifunctional protein with kinase and ion channel activities. Science 291: 1043-1047.

Saito M, Hanson PI, Schlesinger P. 2007. Luminal chloridedependent activation of endosome calcium channels: patch clamp study of enlarged endosomes. J Biol Chem 282: $27327-27333$.

Samie MA, Grimm C, Evans JA, Curcio-Morelli C, Heller S, Slaugenhaupt SA, Cuajungco MP. 2009. The tissue-specific expression of TRPML2 (MCOLN-2) gene is influenced by the presence of TRPML1. Pflugers Arch 459: $79-91$.

Sammels E, Devogelaere B, Mekahli D, Bultynck G, Missiaen L, Parys JB, Cai Y, Somlo S, De Smedt H. 2010. Polycystin-2 activation by inositol 1,4,5-trisphosphateinduced $\mathrm{Ca}^{2+}$ release requires its direct association with the inositol 1,4,5-trisphosphate receptor in a signaling microdomain. J Biol Chem 285: 18794-18805.

Satoh S, Tanaka H, Ueda Y, Oyama J, Sugano M, Sumimoto H, Mori Y, Makino N. 2007. Transient receptor potential (TRP) protein 7 acts as a $\mathrm{G}$ protein-activated $\mathrm{Ca}^{2+}$ channel mediating angiotensin II-induced myocardial apoptosis. Mol Cell Biochem 294: 205-215.

Schilling WP, Goel M. 2004. Mammalian TRPC channel subunit assembly. Novartis Found Symp 258: 18-30.

Schlingmann KP, Sassen MC, Weber S, Pechmann U, Kusch K, Pelken L, Lotan D, Syrrou M, Prebble JJ, Cole DE, et al. 2005. Novel TRPM6 mutations in 21 families with primary hypomagnesemia and secondary hypocalcemia. J Am Soc Nephrol 16: 3061-3069.

Schlingmann KP, Weber S, Peters M, Niemann Nejsum L, Vitzthum H, Klingel K, Kratz M, Haddad E, Ristoff E, Dinour D, et al. 2002. Hypomagnesemia with secondary hypocalcemia is caused by mutations in TRPM6, a new member of the TRPM gene family. Nat Genet 31: $166-170$.

Sharif-Naeini R, Folgering JH, Bichet D, Duprat F, Lauritzen I, Arhatte M, Jodar M, Dedman A, Chatelain FC, Schulte U, et al. 2009. Polycystin-1 and -2 dosage regulates pressure sensing. Cell 139: 587-596.

Shen Y, Heimel JA, Kamermans M, Peachey NS, Gregg RG, Nawy S. 2009. A transient receptor potential-like channel mediates synaptic transmission in rod bipolar cells. J Neurosci 29: 6088-6093.

Shibasaki K, Suzuki M, Mizuno A, Tominaga M. 2007. Effects of body temperature on neural activity in the hippocampus: regulation of resting membrane potentials by transient receptor potential vanilloid 4. J Neurosci 27: $1566-1575$.

Shim S, Yuan JP, Kim JY, Zeng W, Huang G, Milshteyn A, Kern D, Muallem S, Ming G-L, Worley PF. 2009. PeptidylProlyl Isomerase FKBP52 Controls Chemotropic Guidance of Neuronal Growth Cones via Regulation of TRPC1 Channel Opening. Neuron 64: 471-483.

Shimizu T, Janssens A, Voets T, Nilius B. 2009. Regulation of the murine TRPP 3 channel by voltage, $\mathrm{pH}$, and changes in cell volume. Pflugers Arch 457: 795-807. 
Smith GD, Gunthorpe MJ, Kelsell RE, Hayes PD, Reilly P, Facer P, Wright JE, Jerman JC, Walhin JP, Ooi L, et al. 2002. TRPV3 is a temperature-sensitive vanilloid receptor-like protein. Nature 418: 186-190.

Song Y, Dayalu R, Matthews SA, Scharenberg AM. 2006 TRPML cation channels regulate the specialized lysosomal compartment of vertebrate B-lymphocytes. Eur J Cell Biol 85: 1253-1264.

Sours-Brothers S, Ding M, Graham S, Ma R. 2009. Interaction between TRPC1/TRPC4 assembly and STIM1 contributes to store-operated $\mathrm{Ca}^{2+}$ entry in mesangial cells. Exp Biol Med 234: 673-682.

Story GM, Peier AM, Reeve AJ, Eid SR, Mosbacher J, Hricik TR, Earley TJ, Hergarden AC, Andersson DA, Hwang SW, et al. 2003. ANKTM1, a TRP-like channel expressed in nociceptive neurons, is activated by cold temperatures. Cell 112: 819-829.

Strubing C, Krapivinsky G, Krapivinsky L, Clapham DE. 2001. TRPC1 and TRPC5 form a novel cation channel in mammalian brain. Neuron 29: 645-655.

Strubing C, Krapivinsky G, Krapivinsky L, Clapham DE. 2003. Formation of novel TRPC channels by complex subunit interactions in embryonic brain. J Biol Chem 278: 39014-39019.

Su Z, Zhou X, Loukin SH, Haynes WJ, Saimi Y, Kung C. 2009. The use of yeast to understand TRP-channel mechanosensitivity. Pflugers Arch 458: 861-867.

Sun M, Goldin E, Stahl S, Falardeau JL, Kennedy JC, Acierno JS, Bove C, Kaneski CR, Nagle J, Bromley MC, et al. 2000 Mucolipidosis type IV is caused by mutations in a gene encoding a novel transient receptor potential channel. Hum Mol Genet 9: 2471-2478.

Suzuki M, Mizuno A, Kodaira K, Imai M. 2003. Impaired pressure sensation in mice lacking TRPV4. J Biol Chem 278: 22664-22668.

Tai Y, Feng S, Ge R, Du W, Zhang X, He Z, Wang Y. 2008. TRPC6 channels promote dendritic growth via the CaMKIV-CREB pathway. J Cell Sci 121: 2301-2307.

Talavera K, Gees M, Karashima Y, Meseguer VM, Vanoirbeek JA, Damann N, Everaerts W, Benoit M, Janssens A, Vennekens R, et al. 2009. Nicotine activates the chemosensory cation channel TRPA1. Nat Neurosci 12: 1293-1299.

Talavera K, Nilius B, Voets T. 2008. Neuronal TRP channels: thermometers, pathfinders and life-savers. Trends Neurosci 31: 287-295.

Thebault S, Lemonnier L, Bidaux G, Flourakis M, Bavencoffe A, Gordienko D, Roudbaraki M, Delcourt P, Panchin Y, Shuba Y, et al. 2005. Novel role of cold/ menthol-sensitive transient receptor potential melastatine family member 8 (TRPM8) in the activation of storeoperated channels in LNCaP human prostate cancer epithelial cells. J Biol Chem 280: 39423-39435.

Thompson EG, Schaheen L, Dang H, Fares H. 2007. Lysosomal trafficking functions of mucolipin-1 in murine macrophages. BMC Cell Biol 8: 54.

Thyagarajan B, Benn B, Lukacs V, Christakos S, Rohacs T. 2009. Phospholpase $C$ mediated regulation of TRPV6 channels: implications in active intestinal $\mathrm{Ca}^{2+}$ transport. Mol Pharmacology 75: 608-616.

Thyagarajan B, Lukacs V, Rohacs T. 2008. Hydrolysis of phosphatidylinositol 4,5-bisphosphate mediates calcium induced inactivation of TRPV6 channels. J Biol Chem 283: 14980-14987.

Tiruppathi C, Ahmmed GU, Vogel SM, Malik AB. 2006. $\mathrm{Ca}^{2+}$ signaling, TRP channels, and endothelial permeability. Microcirculation 13: 693-708.

Tong Q, Chu X, Cheung JY, Conrad K, Stahl R, Barber DL, Mignery G, Miller BA. 2004. Erythropoietin-modulated calcium influx through TRPC2 is mediated by phospholipase Cgamma and IP ${ }_{3}$ R. Am J Physiol Cell Physiol 287: C1667-C1678.

Topala CN, Groenestege WT, Thebault S, van den Berg D, Nilius B, Hoenderop JG, Bindels RJ. 2007. Molecular determinants of permeation through the cation channel TRPM6. Cell Calcium 41: 513-523.

Tsavaler L, Shapero MH, Morkowski S, Laus R. 2001. Trp-p8, a novel prostate-specific gene, is up-regulated in prostate cancer and other malignancies and shares high homology with transient receptor potential calcium channel proteins. Cancer Res 61: 3760-3769.

Tsiokas L, Kim E, Arnould T, Sukhatme VP, Walz G. 1997. Homo- and heterodimeric interactions between the gene products of PKD1 and PKD2. Proc Natl Acad Sci U S A 94: 6965-6970.

Tsvilovskyy VV, Zholos AV, Aberle T, Philipp SE, Dietrich A, Zhu MX, Birnbaumer L, Freichel M, Flockerzi V. 2009 Deletion of TRPC4 and TRPC6 in mice impairs smooth muscle contraction and intestinal motility in vivo. Gastroenterology 137: 1415-1424.

Turner H, Fleig A, Stokes A, Kinet JP, Penner R. 2003. Discrimination of intracellular calcium store subcompartments using TRPV1 (transient receptor potential channel, vanilloid subfamily member 1) release channel activity. Biochem J 371: 341-350.

Ullrich ND, Voets T, Prenen J, Vennekens R, Talavera K, Droogmans G, Nilius B. 2005. Comparison of functional properties of the $\mathrm{Ca}^{2+}$-activated cation channels TRPM4 and TRPM5 from mice. Cell Calcium 37: 267-278.

Vaca L. 2010. SOCIC: the store-operated calcium influx complex. Cell Calcium 47: 199-209.

van Genderen MM, Bijveld MM, Claassen YB, Florijn RJ, Pearring JN, Meire FM, McCall MA, Riemslag FC, Gregg RG, Bergen AA, et al. 2009. Mutations in TRPM1 are a common cause of complete congenital stationary night blindness. Am J Hum Genet 85: 730-736.

Venkatachalam K, Hofmann T, Montell C. 2006. Lysosomal Localization of TRPML3 Depends on TRPML2 and the Mucolipidosis-associated Protein TRPML1. J Biol Chem 281: 17517-17527.

Venkatachalam K, Long AA, Elsaesser R, Nikolaeva D, Broadie K, Montell C. 2008. Motor deficit in a Drosophila model of mucolipidosis type IV due to defective clearance of apoptotic cells. Cell 135: 838-851.

Venkatachalam K, van Rossum DB, Patterson RL, Ma HT, Gill DL. 2002. The cellular and molecular basis of storeoperated calcium entry. Nat Cell Biol 4: E263-E272.

Vennekens R, Hoenderop JG, Prenen J, Stuiver M, Willems PH, Droogmans G, Nilius B, Bindels RJ. 2000. Permeation and gating properties of the novel epithelial $\mathrm{Ca}(2+)$ channel. J Biol Chem 275: 3963-3969.

Vennekens R, Olausson J, Meissner M, Bloch W, Mathar I, Philipp SE, Schmitz F, Weissgerber P, Nilius B, Flockerzi 
V, et al. 2007. Increased IgE-dependent mast cell activation and anaphylactic responses in mice lacking the calcium-activated nonselective cation channel TRPM4. Nat Immunol 8: 312-320.

Vennekens R, Owsianik G, Nilius B. 2008. Vanilloid transient receptor potential cation channels: an overview. Curr Pharm Des 14: 18-31.

Venugopal B, Browning MF, Curcio-Morelli C, Varro A, Michaud N, Nanthakumar N, Walkley SU, Pickel J, Slaugenhaupt SA. 2007. Neurologic, gastric, and opthalmologic pathologies in a murine model of mucolipidosis type IV. Am J Hum Genet 81: 1070-1083.

Voets T, Droogmans G, Wissenbach U, Janssens A, Flockerzi V, Nilius B. 2004a. The principle of temperaturedependent gating in cold- and heat-sensitive TRP channels. Nature 430: 748-754.

Voets T, Janssens A, Prenen J, Droogmans G, Nilius B. 2003. $\mathrm{Mg}^{2+}$-dependent gating and strong inward rectification of the cation channel TRPV6. J Gen Physiol 121: $245-260$.

Voets T, Nilius B, Hoefs S, van der Kemp AW, Droogmans G, Bindels RJ, Hoenderop JG. 2004b. TRPM6 forms the $\mathrm{Mg}^{2+}$ influx channel involved in intestinal and renal $\mathrm{Mg}^{2+}$ absorption. J Biol Chem 279: 19-25.

Voets T, Prenen J, Fleig A, Vennekens R, Watanabe H, Hoenderop JG, Bindels RJ, Droogmans G, Penner R, Nilius B. 2001. CaT1 and the calcium release-activated calcium channel manifest distinct pore properties. J Biol Chem 276: 47767-47770.

Voets T, Prenen J, Vriens J, Watanabe H, Janssens A, Wissenbach U, Bodding M, Droogmans G, Nilius B. 2002 Molecular determinants of permeation through the cation channel TRPV4. J Biol Chem 277: 33704-33710.

Vriens J, Appendino G, Nilius B. 2009. Pharmacology of vanilloid transient receptor potential cation channels. Mol Pharmacol 75: 1262-1279.

Wang ZY, Wang P, Merriam FV, Bjorling DE. 2008. Lack of TRPV1 inhibits cystitis-induced increased mechanical sensitivity in mice. Pain 139: 158-167.

Watanabe H, Davis JB, Smart D, Jerman JC, Smith GD, Hayes P, Vriens J, Cairns W, Wissenbach U, Prenen J, et al. 2002a. Activation of TRPV4 channels (hVRL-2/ mTRP12) by phorbol derivatives. J Biol Chem 277: 13569-13577.

Watanabe H, Vriens J, Prenen J, Droogmans G, Voets T, Nilius B. 2003. Anandamide and arachidonic acid use epoxyeicosatrienoic acids to activate TRPV4 channels. Nature 424: 434-438.

Watanabe H, Vriens J, Suh SH, Benham CD, Droogmans G, Nilius B. 2002b. Heat-evoked activation of TRPV4 channels in a HEK293 cell expression system and in native mouse aorta endothelial cells. J Biol Chem 277: 47044-47051.

Wedel BJ, Vazquez G, McKay RR, St JBG, Putney JW Jr. 2003. A calmodulin/inositol 1,4,5-trisphosphate $\left(\mathrm{IP}_{3}\right)$ receptor-binding region targets TRPC3 to the plasma membrane in a calmodulin $/ \mathrm{IP}_{3}$ receptor-independent process. J Biol Chem 278: 25758-25765.

Wegierski T, Steffl D, Kopp C, Tauber R, Buchholz B, Nitschke R, Kuehn EW, Walz G, Kottgen M. 2009. TRPP2 channels regulate apoptosis through the $\mathrm{Ca}^{2+}$ concentration in the endoplasmic reticulum. Embo $J$ 28: $490-499$.

Wen Z, Han L, Bamburg JR, Shim S, Ming GL, Zheng JQ. 2007. BMP gradients steer nerve growth cones by a balancing act of LIM kinase and Slingshot phosphatase on ADF/cofilin. J Cell Biol 178: 107-119.

Wheeler GL, Brownlee C. 2008. Ca(2+) signalling in plants and green algae - changing channels. Trends Plant Sci 13: 506-514.

Wisnoskey BJ, Sinkins WG, Schilling WP. 2003. Activation of vanilloid receptor type I in the endoplasmic reticulum fails to activate store-operated $\mathrm{Ca}^{2+}$ entry. Biochem J 372: 517-528.

Wolf FI, Cittadini A. 1999. Magnesium in cell proliferation and differentiation. Front Biosci 4: D607-D617.

Worley PF, Zeng W, Huang GN, Yuan JP, Kim JY, Lee MG, Muallem S. 2007. TRPC channels as STIM1-regulated store-operated channels. Cell Calcium 42: 205-211.

Xi Q, Adebiyi A, Zhao G, Chapman KE, Waters CM, Hassid A, Jaggar JH. 2008. $\mathrm{IP}_{3}$ constricts cerebral arteries via $\mathrm{IP}_{3}$ receptor-mediated TRPC 3 channel activation and independently of sarcoplasmic reticulum $\mathrm{Ca}^{2+}$ release. Circ Res 102: $1118-1126$.

Xiao Y, Lv X, Cao G, Bian G, Duan J, Ai J, Sun H, Li Q, Yang Q, Chen T, et al. 2010. Overexpression of Trpp5 contributes to cell proliferation and apoptosis probably through involving calcium homeostasis. Mol Cell Biochem 339: $155-161$.

Xu H, Delling M, Jun JC, Clapham DE. 2006. Oregano, thyme and clove-derived flavors and skin sensitizers activate specific TRP channels. Nat Neurosci 9: 628-635.

Xu H, Ramsey IS, Kotecha SA, Moran MM, Chong JA, Lawson D, Ge P, Lilly J, Silos-Santiago I, Xie Y, et al. 2002. TRPV3 is a calcium-permeable temperaturesensitive cation channel. Nature 418: 181-186.

Yeh BI, Kim YK, Jabbar W, Huang CL. 2005. Conformational changes of pore helix coupled to gating of TRPV5 by protons. Embo J 24: 3224-3234.

Yildirim E, Birnbaumer L. 2007. TRPC2: molecular biology and functional importance. Handb Exp Pharmacol: 53-75.

Yoder BK, Hou X, Guay-Woodford LM. 2002. The polycystic kidney disease proteins, polycystin-1, polycystin-2, polaris, and cystin, are co-localized in renal cilia. J Am Soc Nephrol 13: 2508-2516.

Yoshida T, Inoue R, Morii T, Takahashi N, Yamamoto S, Hara Y, Tominaga M, Shimizu S, Sato Y, Mori Y. 2006. Nitric oxide activates TRP channels by cysteine Snitrosylation. Nat Chem Biol 2: 596-607.

Yu PC, Gu SY, Bu JW, Du JL. 2010. TRPC1 Is Essential for In Vivo Angiogenesis in Zebrafish. Circ Res 106: 1221-1232.

Yuan JP, Kim MS, Zeng W, Shin DM, Huang G, Worley PF, Muallem S. 2009. TRPC channels as STIM1-regulated SOCs. Channels (Austin) 3: 221-225.

Yuan JP, Zeng W, Huang GN, Worley PF, Muallem S. 2007. STIM1 heteromultimerizes TRPC channels to determine their function as store-operated channels. Nat Cell Biol 9: 636-645.

Zechel S, Werner S, von Bohlen Und Halbach O. 2007. Distribution of TRPC4 in developing and adult murine brain. Cell Tissue Res 328: 651-656. 
Zeilhofer HU, Kress M, Swandulla D. 1997. Fractional Ca ${ }^{2+}$ currents through capsaicin- and proton-activated ion channels in rat dorsal root ganglion neurones. J Physiol 503: 67-78.

Zhang F, Jin S, Yi F, Li PL. 2009. TRP-ML1 functions as a lysosomal NAADP-sensitive $\mathrm{Ca}^{2+}$ release channel in coronary arterial myocytes. J Cell Mol Med 13: 3174-3185.

Zhang F, Li PL. 2007. Reconstitution and characterization of a nicotinic acid adenine dinucleotide phosphate (NAADP)-sensitive $\mathrm{Ca}^{2+}$ release channel from liver lysosomes of rats. J Biol Chem 282: 25259-25269.

Zhang L, Barritt GJ. 2004. Evidence that TRPM8 is an androgen-dependent $\mathrm{Ca}^{2+}$ channel required for the survival of prostate cancer cells. Cancer Res 64: 8365-8373.

Zhang W, Chu X, Tong Q, Cheung JY, Conrad K, Masker K, Miller BA. 2003a. A novel TRPM2 isoform inhibits calcium influx and susceptibility to cell death. J Biol Chem 278: $16222-16229$.

Zhang W, Hirschler-Laszkiewicz I, Tong Q, Conrad K, Sun SC, Penn L, Barber DL, Stahl R, Carey DJ, Cheung JY,
TRP Channels Modulate $\mathrm{Ca}^{2+}$ Signaling

et al. 2006. TRPM2 is an ion channel that modulates hematopoietic cell death through activation of caspases and PARP cleavage. Am J Physiol Cell Physiol 290: C1146-C1159.

Zhang Y, Hoon MA, Chandrashekar J, Mueller KL, Cook B, Wu D, Zuker CS, Ryba NJ. 2003b. Coding of sweet, bitter, and umami tastes: different receptor cells sharing similar signaling pathways. Cell 112: 293-301.

Zhang Z, Reboreda A, Alonso A, Barker PA, Seguela P. 2010. TRPC channels underlie cholinergic plateau potentials and persistent activity in entorhinal cortex. Hippocampus (in press).

Zong X, Schieder M, Cuny H, Fenske S, Gruner C, Rotzer K, Griesbeck O, Harz H, Biel M, Wahl-Schott C. 2009. The two-pore channel TPCN2 mediates NAADP-dependent $\mathrm{Ca}(2+)$-release from lysosomal stores. Pflugers Arch 458: 891-899.

Zurborg S, Yurgionas B, Jira JA, Caspani O, Heppenstall PA. 2007. Direct activation of the ion channel TRPA1 by $\mathrm{Ca}(2+)$. Nat Neurosci 10: 277-279. 


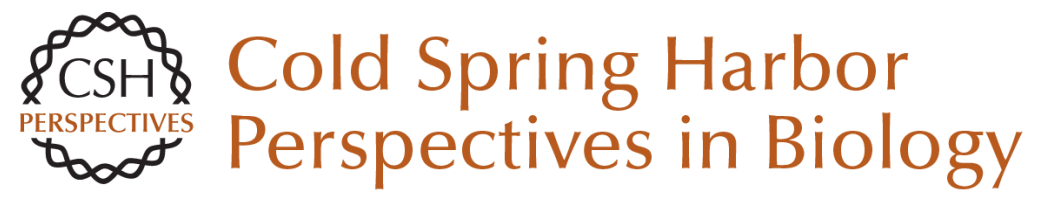

\section{The Role of Transient Receptor Potential Cation Channels in $\mathrm{Ca}^{2+}$ Signaling}

Maarten Gees, Barbara Colsoul and Bernd Nilius

Cold Spring Harb Perspect Biol 2010; doi: 10.1101/cshperspect.a003962 originally published online September 22, 2010

\section{Subject Collection Calcium Signaling}

The Endoplasmic Reticulum-Plasma Membrane Junction: A Hub for Agonist Regulation of $\mathrm{Ca}^{2+}$ Entry

Hwei Ling Ong and Indu Suresh Ambudkar

Calcium-Handling Defects and Neurodegenerative

Disease

Sean Schrank, Nikki Barrington and Grace E. Stutzmann

Lysosomal $\mathrm{Ca}^{2+}$ Homeostasis and Signaling in Health and Disease

Emyr Lloyd-Evans and Helen Waller-Evans

$\mathrm{Ca}^{2+}$ Signaling in Exocrine Cells

Malini Ahuja, Woo Young Chung, Wei-Yin Lin, et al.

Functional Consequences of Calcium-Dependent Synapse-to-Nucleus Communication: Focus on Transcription-Dependent Metabolic Plasticity Anna M. Hagenston, Hilmar Bading and Carlos Bas-Orth

Identifying New Substrates and Functions for an Old Enzyme: Calcineurin

Jagoree Roy and Martha S. Cyert

Fundamentals of Cellular Calcium Signaling: A

Primer

Martin D. Bootman and Geert Bultynck
Primary Active $\mathrm{Ca}^{2+}$ Transport Systems in Health and Disease

Jialin Chen, Aljona Sitsel, Veronick Benoy, et al.

Signaling through $\mathrm{Ca}^{2+}$ Microdomains from

Store-Operated CRAC Channels

Pradeep Barak and Anant B. Parekh

Structural Insights into the Regulation of $\mathrm{Ca}^{2+}$ /Calmodulin-Dependent Protein Kinase II (CaMKII) Moitrayee Bhattacharyya, Deepti Karandur and John Kuriyan

Store-Operated Calcium Channels: From Function to Structure and Back Again Richard S. Lewis

Bcl-2-Protein Family as Modulators of $\mathrm{IP}_{3}$

Receptors and Other Organellar $\mathrm{Ca} 2+$ Channels Hristina Ivanova, Tim Vervliet, Giovanni Monaco, et al.

Calcium Signaling in Cardiomyocyte Function Guillaume Gilbert, Kateryna Demydenko, Eef Dries, et al.

Cytosolic $\mathrm{Ca}^{2+}$ Buffers Are Inherently $\mathrm{Ca}^{2+}$ Signal Modulators Beat Schwaller

For additional articles in this collection, see http://cshperspectives.cshlp.org/cgi/collection/

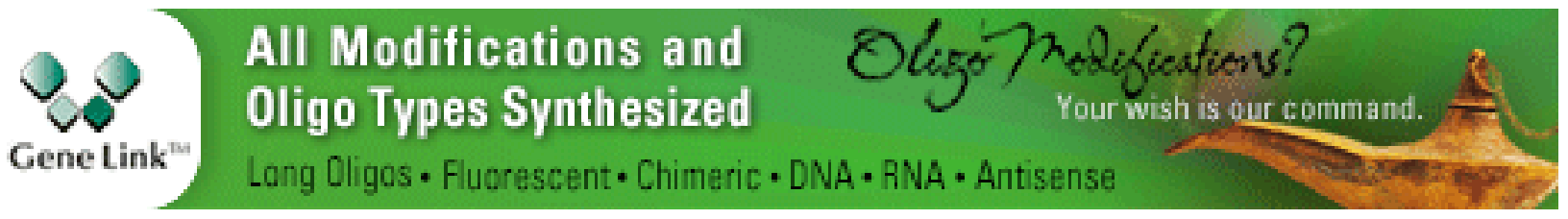


Role of Two-Pore Channels in Embryonic Development and Cellular Differentiation Sarah E. Webb, Jeffrey J. Kelu and Andrew L. Miller

\section{Organellar Calcium Handling in the Cellular \\ Reticular Network}

Wen-An Wang, Luis B. Agellon and Marek Michalak

For additional articles in this collection, see http://cshperspectives.cshlp.org/cgi/collection/

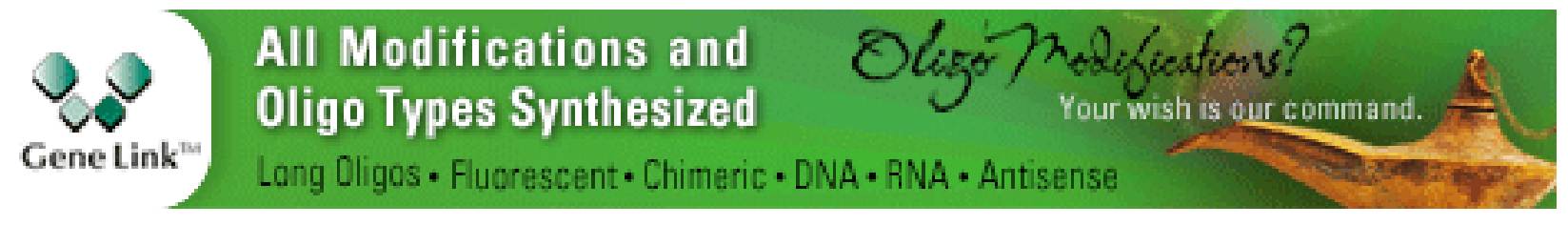

Copyright @ 2010 Cold Spring Harbor Laboratory Press; all rights reserved 